IZA DP No. 3845

\title{
Education and Mobility
}

Stephen Machin

Panu Pelkonen

Kjell G. Salvanes

November 2008 


\title{
Education and Mobility
}

\author{
Stephen Machin \\ University College London, \\ CEE, CEP, London School of Economics \\ and IZA \\ Panu Pelkonen \\ CEE, CEP, London School of Economics
}

Kjell G. Salvanes

Norwegian School of Economics,

CEE, London School of Economics,

and IZA

\section{Discussion Paper No. 3845 \\ November 2008}

\author{
IZA \\ P.O. Box 7240 \\ 53072 Bonn \\ Germany \\ Phone: +49-228-3894-0 \\ Fax: +49-228-3894-180 \\ E-mail: iza@iza.org
}

\begin{abstract}
Any opinions expressed here are those of the author(s) and not those of IZA. Research published in this series may include views on policy, but the institute itself takes no institutional policy positions.

The Institute for the Study of Labor (IZA) in Bonn is a local and virtual international research center and a place of communication between science, politics and business. IZA is an independent nonprofit organization supported by Deutsche Post World Net. The center is associated with the University of Bonn and offers a stimulating research environment through its international network, workshops and conferences, data service, project support, research visits and doctoral program. IZA engages in (i) original and internationally competitive research in all fields of labor economics, (ii) development of policy concepts, and (iii) dissemination of research results and concepts to the interested public.
\end{abstract}

IZA Discussion Papers often represent preliminary work and are circulated to encourage discussion. Citation of such a paper should account for its provisional character. A revised version may be available directly from the author. 
IZA Discussion Paper No. 3845

November 2008

\section{ABSTRACT}

\section{Education and Mobility}

We show that the length of compulsory education has a causal impact on regional labour mobility. The analysis is based on a quasi-exogenous staged Norwegian school reform, and register data on the whole population. Based on the results, we conclude that part of the USEurope difference, as well as the European North-South difference in labour mobility, is likely to be due to differences in levels of education in the respective regions.

JEL Classification: $\quad$ I28, J24, J61

Keywords: $\quad$ education, mobility, labour market

Corresponding author:

Panu Pelkonen

CEP

London School of Economics and Political Science

Houghton Street

London WC2A 2AE

United Kingdom

E-mail: p.o.pelkonen@lse.ac.uk

\footnotetext{
* The authors would like to thank seminar participants at University of Essex, University College London, Uppsala University, Royal Economic Society annual conference 2008, the 3rd Nordic Summer Institute in Labour Economics and ESPE 2008 annual conference for criticisms and suggestions. Panu Pelkonen would like to thank Yrjö Jahnsson's foundation for generous support during his PhD studies at University College London, and Kjell Salvanes would like to thank the Ministry of Labour and the Norwegian Research Council for support.
} 


\section{Introduction}

Labour mobility has long been viewed as a crucial component in the functioning of the labour markets of different countries. By mobility we mean within-country migration in particular, where a worker relocates to a different part of the country to find a better labour market match. Indeed, regional labour mobility has moved towards the top of the research agenda, especially in Europe, where regional unemployment differentials have been persistently larger than in the United States (Baddeley et al., 1998, Decressin and Fatas, 1995, Blanchard and Katz, 1992). The unification of the European monetary policy within the EMU has further raised the importance of both national and international migration as a macroeconomic adjustment mechanism within the EU (OECD, 1986).

However, the notion that education interplays closely with the labour mobility of individuals has, to date, received far less attention. We know that the attainment of a higher level of education tends to open up new opportunities in the labour market (McCormick, 1997). Thus, if labour markets for skilled workers have a national dimension, a higher level of education should increase the likelihood of mobility, especially if the worker lives in a region with a higher unemployment rate.

Fully understanding the reasons why the less educated are less mobile remains difficult to pin down. It may be that lack of information, lack of skills learned in higher education, credit constraints or other unobserved characteristics correlated with lower education impede mobility among this group. Assessing the causal impact of education on mobility is therefore a serious empirical challenge since education and mobility could be co-determined by other factors such as personality characteristics or parental background, for instance. Thus, even though education is connected to mobility, we do not know whether it is because of a selection of people or due to the 
effect of education per se. In this paper, we study one key aspect of this by exploring the role of compulsory education in facilitating mobility. ${ }^{1}$

International comparisons can shed some light on the issue of the connection between education and regional mobility since low mobility of low education individuals seems to characterise some countries more than others. In the UK for instance, it has been observed that the unemployment rates of highly educated workers have remained relatively similar across regions, implying that migration from high to low unemployment areas has levelled the employment opportunities across regions. In contrast, the unemployment rate of less educated workers has remained starkly different across regions (Gregg, Machin and Manning, 2004). The main explanation for this pattern has been that professional job market operates on a national basis and that the manual or unskilled job market tends to be more localised (McCormick, 1997, Hughes and McCormick, 1994, 1987). On the other hand, in the United States less educated workers are relatively mobile compared to the UK, and the reasons for the differences between the two countries are not well known.

Some commentators have suggested that Europeans appear to respond less strongly to regional unemployment differences (Bentivogli and Pagano, 1999), indicating higher costs of moving. Some specific suggestions as to what these costs are, have been provided for example by Oswald (1999) (house ownership), Belot and Ederveen (2005) (property transaction costs), Spilimbergo and Ubeda (2002) (local

\footnotetext{
${ }^{1}$ There is hardly any causal analysis of connections between labour mobility and education. One exception, which takes a rather different approach to us, is the US study of Malamud and Wozniak (2008). They use Vietnam war draft risk to instrument the probability of college graduation thus studying the upper end of the education distribution. We consider the lower end where, as we discuss at length in this paper, many believe problems of low mobiliy exist.
} 
social networks and numerous other variables), Antolin and Bower (1997) (unemployment benefits), and Belot (2007) (labour market protection). ${ }^{2}$

Data however suggests there is a solid relationship between national levels of education and mobility. Figures 1-3 plot the years of education of the total population, based on the Barro-Lee (2001) schooling dataset, to three different measures of mobility for a cross-section of European countries. The first one is the regional migration rate calculated by Huber (2004) for 1983 based on the Cronos dataset. ${ }^{3}$ The second measure is based on the Eurobarometer (2001a) survey question, which asks whether the respondent has moved house within the last 10 years. The last measure also comes from Eurobarometer (2001b) survey, which asked whether people are attached to their own town or village. We report the figures for those answering either "Not at all attached" or "Not very Attached". ${ }^{4}$ All three measures suggest a relationship between education and mobility. The plots also reveal a rather clear distinction between less mobile southern Europe and more mobile northern Europe. ${ }^{5}$

Comparison of mobility rates between the US and Europe for the mid-1980s (as in Figure 1) shows that the US has clearly higher levels of mobility. The US Census shows that the rate of inter-state mobility in $1983-84$ was $2.8 \%$ of the population, while the inter-county migration rate was as high as $6.4 \%$. Mobility rates remained fairly constant in the US over the 1980s and 1990s (US Census 1986, 1997).

\footnotetext{
${ }^{2}$ There have been very few attempts to jointly assess the relative importance of the different possible factors that may affect cross-country differences in regional mobility. One recent attempt (Huber, 2004) finds that most of the mobility differences can be explained by variations in employment protection, international migration, house ownership and average region size of the country. Notably for our work, his study does not include variables relating to education.

${ }^{3}$ Countries for which the data are from a different year than 1983 are: UK and Portugal (1985); Denmark (1990); and Austria (1995). In Figure 1, we have also added data for Norway and United States. The Norwegian mobility rate across counties is calculated from the data we use for 1986-1987, and the US figures are from the US Census (1983-84).

${ }^{4}$ Table A1 in the Appendix provides the data points and countries used in Figures 1-3.

${ }^{5}$ This has been noted elsewhere, recently in the work by David et al (2008a, 2008b) which argues that localise social capital is accumulated more in Southern than Northern Europe and helps explain some of the observed unemployment differences in Europe.
} 
Education levels in the US are also higher. According to the Barro-Lee dataset, the US had 11.56 years of education per person in 1985. Interestingly for our analysis, in the US, where labour mobility is higher, the compulsory schooling period is longer than in most European countries. ${ }^{6}$

In this paper, we explore the role of compulsory education in facilitating mobility. We study an educational reform which increased the years of compulsory schooling in Norway by two years. From a research modelling perspective, this reform is particularly attractive for at least three main reasons. Firstly, the timing of the reform is geographically dispersed in a quasi-random fashion, and secondly it increased the minimum years of schooling by a large amount. This is why we think it offers a good opportunity for credible inference in an instrumental variable framework. Thirdly, it has external validity, since reforms of this type were carried out in many other European countries after the Second World War. ${ }^{7}$

The results of this study can be relevant for several reasons. If we assume that the additional level of education arising from the reform reflect the effect of general education and skills, the results could support the extension of compulsory education in Europe closer to the levels of the US. Then, the results could also be directly relevant for non-European countries with similar socio-economic and geographical features.

However, there is a trade-off in research strategy, where one can have good generalisability, but poor causal inference (cross-county studies), or good causal inference with a lower degree of generalisability and external validity (case-specific

\footnotetext{
${ }^{6}$ See also McCormick (1997) who, when discussing differences in labour mobility between the US and the UK, emphasised that the transatlantic difference in the years of schooling for manual workers is fairly large.

${ }^{7}$ For instance, in Germany from 1949 to 1969, Finland (1972-1977) and in Sweden (1950-1959). For overviews, see Leschinsky and Mayer (1990), or Viarengo (2007). Several recent studies have focused on these reforms (see, inter alia, Meghir and Palme, 2005, Pekkarinen, Uusitalo and Pekkala, 2006, and Holmlund, 2007, Aakvik, Salvanes and Vaage, 2008, Black, Devereux and Salvanes, 2005).
} 
instrumental variable studies). Clearly, because the reform used here binds primarily at the lowest part of the educational distribution our study (at least partially) reflects this trade-off. Further, it needs to be acknowledged that the reform not only represents a rise in education in terms of content and years, but also an institutional change, which extends the compulsory period that children are kept in schools. At such an age, both the skills learned and the fact that entry to the labour market is prolonged by statute may make a difference to future labour market outcomes.

One might also argue that skills learned between grades 7-9 differ from those learned at higher grades. However, such skills may still be of crucial importance in terms of one's labour market outcomes. Even if most industrial countries would have extended compulsory schooling beyond 7 years, this clearly is not the case in a large number of lower income countries, in which such school reforms are yet to be carried out. It is not quite possible to disentangle these factors from one another in this study, but certainly we are studying the effects of a change in the educational system the goal of which was to improve education levels and unify the quality of education.

Using data for Norwegian birth cohorts from 1947 to 1958, matched to data on their parental background and different compulsory schooling regimes, we estimate statistical models treating the following regional mobility outcomes as a function of education; the annual propensity to move to another county; the total number of regional migrations over a 17 year period; and the probability of moving to an urban area. In addition, we consider the labour market effects of education by studying the causal impact of education on employment and earnings. Our results suggest clear positive effects of education in term of mobility, and that a substantial proportion of the observed unconditional covariance between education and mobility is causal. 
There are several possible channels via which education levels can affect individual's location choices. We test some of these as well as undertake several robustness tests.

The rest of the paper is structured as follows. Section 2 gives an overview of the Norwegian labour market, especially focusing on education, mobility and regional employment differences. Section 3 contains a detailed description of the school reform and the data used in this study. Section 4 presents the empirical strategy and the results, and section 5 concludes.

\section{Education, Mobility and the Norwegian Labour Market}

Norway as a whole has enjoyed relatively low rates of unemployment, and rates of regional mobility typical of Northern Europe. But as the statistics are broken down by age and education, prominent differences arise. Figure 4 plots the educational composition of the working age population over 1986 to 2002. As expected, the proportion of the workforce who have completed more than primary education has been on a secular rise. The proportion with minimum qualifications has decreased from $25 \%$ percent of the workforce to less than $15 \%$.

Figure 5 plots the life-cycle employment rates of men by education levels. ${ }^{8}$ It is clear that college educated workers enter the workforce later, but achieve highest employment rates (above 80\%), especially towards the end of their careers. Employment rate of workers with only primary education remains low at around the $60 \%$ level.

In general, one would expect that regional variations in employment rates would level off via migration. Figures 6A-6C show education group-specific trends of

\footnotetext{
${ }^{8}$ Being in the labour force is not directly observable in the data. We define a person as being employed if he/she either has an employer code, or is self-employed. With this definition, the employment rate in 1999 for age group 16-74 would be 64\% in our data, while based on Norwegian Labour Market Surveys (Statistics Norway, 1998), the employment rate for the same age group is $70 \%$. The difference between the two is that we do not count workers temporarily out of the labour force and unemployed.
} 
employment rates of 20-65 year old people for Norway's 19 mainland counties. A clear pattern emerges: regional disparities in labour market participation have remained high for workers with only compulsory education (Figure 6A). For workers with secondary education, the regional disparities have converged little, but only little, and disparities remain high (Figure 6B). Lastly, in Figure 6C, it can be seen that the employment rates of individuals with a tertiary education show less variation across regions and have also converged considerably over 1986 to 2002.

To what extent do these differences in the functioning of the labour market result from mobility? Can education - especially compulsory education - increase mobility of the workforce? Figure 7 to some extent provides an answer to the first question. It plots education-specific migration rates of men by age. The migration rate is defined as the probability to move from region to another within a year. It shows that workers with tertiary education tend to be most mobile in their late 20s, whereas for other groups the peak is in their early 20s. This pattern is most likely to be explained by the fact that workers move when they have graduated. ${ }^{9}$ It is also notable that the migration rates of workers with primary versus secondary education do not differ much from each other.

Table 1 shows employment transition matrices for migrants and non-migrants. On average $3 \%$ of the workers are regionally mobile each year. The mobile individuals are much more likely to enter the labour force or exit it. The net increase in labour market participation - entries minus exits - is much larger for regionally mobile people (4\%) than for the non-mobile (1\%). This very much confirms that regional mobility is strongly associated with labour market events.

\footnotetext{
${ }^{9}$ The average age for completion of a masters' degree in Norway is roughly 28 years.
} 
Figure 7 and Table 1 essentially establish the stylised fact that mobility patterns are at least partially behind persistent regional differences in unemployment and labour market participation. For the purposes of policy, our main goal is to evaluate whether the observed connection between education and mobility is causal, or merely reflects unobserved characteristics. As the main driver of our empirical analysis and identification strategy, we utilise the school reform, which is described in detail in the next section of the paper.

\section{Description of the School Reform}

The school reform in Norway is similar to many reforms carried out in European countries over the latter half of the $20^{\text {th }}$ century. The initiation of the reform dates to 1959, when the Norwegian Parliament passed the required legislation. The purpose of the policy was not only to increase educational attainment, but also to unify education at the expense of tracking, reduce regional disparities and broaden access to further education. Specifically, in the old system, there were seven mandatory years of primary education (folkeskole). In addition to these, some municipalities provided a possibility to continue primary school in so called continuation schools (framhaldskole), for one or two years. Secondary education took the form of either a 3 or a 5-year track of general education preparing for academic education (middelskole, or realskole + gymnas), which was typically available in cities and other central places. Further, vocationally oriented schooling was available, typically lasting one or two years (yrkeskole). The new system increased the years of compulsory education to 9, and provided options for further studies, either an academically oriented 3-year high school with an expanded intake, or a vocational schooling (Lie 1973). 
The curriculum for the additional 2 years in the new school system concentrated on core skills of literacy and writing, numerical skills, general knowledge and foreign language. Thus, it became similar to the secondary schooling that previously had been reserved for a minority. As in other countries with similar reforms, these curricular changes were designed to match the increased demand for skilled workers both in services and manufacturing.

The reform started originally as a designed experiment in six municipalities, chosen by the Ministry of Education, until it was made compulsory by the central government. Once the legislation was passed in 1959 municipalities were required to implement the reform by the end of 1972, but were given the liberty to decide the exact timing by themselves. The central government supported the reform financially (for example by completely covering the costs of new schools), consistently with the idea that the reform should reduce regional disparities.

To implement the reform, municipalities were required to present a plan to the central government regarding needs for new teachers, buildings and other costs. The plan was approved by a selection committee at the central level. Thus the final timing of the reform across municipalities was partly determined by a bureaucratic process. Also “dynamic” school directors have been pinpointed as a reason for quicker adoption (Aakvik, Salvanes and Vaage, 2008).

The majority of reforms were implemented between 1961 and 1972, affecting birth cohorts 1947-1958. This study is based on these cohorts, since for these, data for a substantial number of reformed and non-reformed municipalities can be obtained. However, the total set of birth cohorts that received education in the two different school systems corresponds to individuals born between 1946 and 1961. 
The school reform utilised in our empirical work has been used in previous empirical research by Black, Devereux and Salvanes (2005) who used it to identify the causal intergenerational transmission of education from mothers to their children and by Aakvik et al. (2008) to measure private returns to education. In 1960, when the reform started, Norway consisted of 732 municipalities, 665 for which the year of reform is known, or can be plausibly estimated, based on the work by Ness (1971), Aakvik et al. (2008) and Black et al. (2005). For the remaining 67 municipalities the reform was either staged over several years or it is unclear when the reform took place. The geographical distribution of the timing of the reform is demonstrated in Figure 8. It shows that the spread of the reform was not concentrated in certain parts of the country and that early, middle and late reforming municipalities are represented in all parts of the country.

\subsection{Were the municipal differences in the timing of the school reform random?}

For our identification strategy, it will not be necessary that the timing of the reform is independent of fixed municipality characteristics, because we will control for municipality fixed effect. It is however informative to assess what factors, if any, would predict the timing of the reform across municipalities. Previous work by Lie (1973) finds no relation between the timing of the reform and municipal characteristics such as average earnings and education level. Lie however found that in a sub-sample of rural municipalities, politically left-leaning and demographically young municipalities implemented the reform earlier than others. Further, she found that municipalities' reform year depends on the timing of their neighbouring municipalities. Black et al. (2005) regress the year of reform on municipality averages of education, income and age, rate of unemployment, total population, industrial structure, county dummies and the share of votes received by the Norwegian Labour 
party in elections at the beginning of the reform. ${ }^{10}$ They find that apart from the county dummies, none of the explanatory variables are statistically significant. The inclusion of the Labour Party vote share was important, since the Labour party was likely to be the most active party promoting the reform. ${ }^{11}$

We replicate here a similar analysis along the lines of Black et al. (2005), but add even more variables depicting pre-reform political indicators. Table 2 shows two municipality-level cross-sectional OLS estimations, with and without county controls, where municipal characteristics are used to predict the timing of the reform. The dependent variable is the birth year of the first reformed cohort, and the explanatory variables are as listed in the Table. We find the same result as Black et al. - that only the county dummies are significant, reflecting spatial correlations in the timing of the reform. The low proportion of the variance attributable to the regressors is also worth noting. If the county dummies are omitted (Column 2, Table 2), only the log mean income of the municipality is near to being significant at the $5 \%$ level in explaining the timing of the reform.

Table 3 shows the distribution of years of education before and after the reform for cohorts 1947-1958 (panel A), and cohorts 1952-1954 (panel B). Rather than using cohorts 1947-1958, in panel B one can improve the visual comparability of the treatment and control group by narrowing down the number of cohorts, so that the effect of rising education levels across cohorts is minimised. The bottom of the educational distribution shifted upwards by two years, and this affected roughly 10$15 \%$ of people. We also see that the category with 12 years of education increased

\footnotetext{
${ }^{10}$ Norway has 19 mainland counties, each on average including more than 20 municipalities.

${ }^{11}$ According to Lindbekk (1993) the reform was "not politically controversial”, although it was based on "social democratic principles".
} 
slightly, but the difference between panels A and B suggests that this is largely due to the trend growth in education across cohorts. ${ }^{12}$

\subsection{Data}

The data used in this study is a combination of administrative register datasets described in Møen, Salvanes and Sørensen (2004). The data covers all Norwegians aged 16-74 over the period 1986-2002, and provides information about their labour market status, income, educational attainment, age, marital status as well as neighbourhood of residence and a parental identifier. The data can further be linked to parental information from the census of 1960. This parental information includes variables such as occupation, education, sector of employment and municipality of residence. Importantly, the treatment status of the individuals is based on their mothers' municipality of residence in 1960. In 1960, the cohorts 1947-58 were in ages 2-13, and we assume that they received their schooling wherever they were at that point. The 1947-58 cohorts that are the focus of this study can be identified by their age in the administrative registers over 1986-2002. In 1986 the age of these cohorts ranges from 28 to 39 and in 2002 from 44 to 55. Thus, the effects we estimate refer to individuals in their mid-careers, spanning ages 28-55.

\section{Included cohorts and their ages in different cross sections}

\begin{tabular}{|l|c|c|}
\hline Birth Cohort & Age by 1986 (data starts) & Age by 2002 (data ends) \\
\hline 1947 (oldest) & 39 & 55 \\
\hline 1958 (youngest) & 28 & 44 \\
\hline
\end{tabular}

To improve the strength of the reform as an instrumental variable, it is helpful to focus on the bottom end of the educational distribution, where most of the change took place. Table 3 supports the view that the main effect of the reform has been to

\footnotetext{
${ }^{12}$ The drop in 10 years of education is due to abolishment of a 3-year realskole (middle school) track, which could be taken after the mandatory 7 years.
} 
shift people who would have otherwise received 7-9 years of education to the new minimum of 9 years. We cannot rule out the possibility that some individuals, once "pushed" to 9 years, would continue further, even if they would not in the absence of the reform. This means that as the reformed and the non-reformed individuals below 10 years of schooling are considered to be the treatment and the control group, it may be the case that some treated individuals will exit the sample.

The data used in this analysis is individual-level panel data that includes all Norwegians who fulfil four criteria: 1) Their treatment status regarding the school reform can be inferred ${ }^{13}$, 2) they are present in the data in every year 1986-2002 (balanced panel) ${ }^{14}$, and 3) they do not have more than nine years of schooling, and (4) all outcome variables of interest must be present. A total of 67,608 individuals are included. With 17 data points for each, the total number of yearly observations is $1,149,336$ or $1,081,728$ (if the variable is based on changes taking place from year to year). Some aggregate outcomes from the whole 17-year period for these individuals are presented in Table 4. The summary statistics of the balanced panel are presented in Table 7.

The impact of the reform on the educational distribution within our sample can be seen from Figure 9 where we have plotted the deviation from mean years of education before and after the reform. Since the reform occurred in different years for different municipalities, the actual year varies by municipality. We see from the Figure that there is a substantial increase in the average years of education following

\footnotetext{
${ }^{13}$ The cohorts 1947-1958 can be linked to their mothers' municipalities of residence in 1960 via the register data from 1986. Roughly 98 percent of the individuals in these cohorts are present in the 1986 register data. The remaining 2 percent may have emigrated or died. For $80 \%$ of individuals, the register data in 1986 shows the municipality where their mother lived in 1960. It is assumed that individual had their schooling in the municipalities they lived in 1960, when in ages 2-13.

${ }^{14}$ Due to using a balanced panel we loose $5.5 \%$ of potential observations. The people who exit the register data either die or emigrate. There is no statistically significant difference in the exit rate between those who went to the new or old school system.
} 
the reform of about 0.7 years, when comparing a year before the reform to a year after the implementation. This offers descriptive evidence of a strong 'first stage' in our analysis which is next subjected to much more stringent empirical testing in our statistical analysis which comes next.

\section{The Impact of Education on Mobility and Labour Market Outcomes}

This section provides an analysis of the effects of schooling from two points of view. Sections 4.1 to 4.3 provide a life-cycle analysis of the effects by aggregating some individual-level outcomes over 17 years such as the total number a person migrates, the number of years employed, the destination of migration, and assessing to what extent the education induced by the school reform affected life-cycle outcomes. In section 4.4, we use individual-level panel data to estimate the effect of education on annual mobility rates. Importantly, this section also lets us study the possibility of heterogeneous effects in some detail.

\subsection{Life-cycle analysis of the school reform}

Our life-cycle analysis considers a cross-sectional instrumental variable model, incorporating fixed effects for the municipality of growing up, for the various dependent variables of interest for birth cohorts from 1947 to $1958 .{ }^{15}$ Formally, the approach can be represented in terms of the following two equation system:

$$
\begin{gathered}
\text { Outcome }_{i}=\alpha+\beta E d_{i}+\theta D_{\text {Female }}+\sum_{c} \lambda_{c} D_{c}+\Omega_{m}+\varepsilon_{i} \\
\text { Ed }_{i}=\eta+\text { STreated }_{i}+\varphi D_{\text {Female }}+\sum_{c} \psi_{c} D_{c}+\Omega_{m}+v_{i}
\end{gathered}
$$

\footnotetext{
${ }^{15}$ We consider linear probability models with binary outcome dependent variables. The reason for this is that estimations with IV-probit were in some cases not possible to carry out due to the inclusion of municipality fixed effects. We have, however, replicated our results using only county controls, and estimated the models both as linear probability and probit models. The results proved to be very similar to each other and are available from the authors on request.
} 
where "Treated" is a dummy variable indicating whether the person has gone through a reformed school system, based. The model controls for birth cohorts $\left(D_{c}\right)$ and includes municipality fixed effects, $\Omega_{m}$.

In the first stage of the instrumental variable model (equation $1 \mathrm{~b}$ ), $\delta$ measures how much the reform increased the years of education. The attained years of education are taken from 2002, when the subjects were aged 44 to 55 . The main concern or threat to identification is whether the treatment status, which varies within municipalities and cohorts, constitutes a valid instrument. Firstly, as we control for fixed effects for the municipality where the person grew up, we control for all observable and unobservable fixed characteristics of municipality. However, to achieve identification we still require the assumption that trends of such municipality characteristics over time are not correlated with the timing of the reform and that the municipality effects in the second stage (1a) are exogenous. Secondly, as the reform changed not only the quantity, but the quality of the schooling, the possibility remains that our estimates of $\beta$ will be upward biased.

Long term outcomes calculated over 1986-2002 are used as dependent variables, and the four we consider are defined as follows:

1. The number of times the person migrates from one county to another over $1986-2002 .^{16}$

2. The number of years the person is not employed, out of the 17 years of data.

3. Total earnings in 1998. Sample at ages 40-51.

4. Whether the individual lives in one of the nine largest towns in 2002.

\footnotetext{
${ }^{16}$ Defined as the number of changes in county code observed in the register data. To avoid the possibility that migrations to and from Oslo- the largest county in terms of population - and its neighbouring county Akershus should drive the results, we treated Oslo and the adjacent Akershus as a single county.
} 


\subsection{Results from life-cycle analysis}

The results for all four outcomes, implemented model (1a)-(1b), are presented in Table 5. Summary statistics of the data used in the regressions are given in Table 4. In the first column of the Panels of Table 5, the effect of the reform on the years of education is highly significant, and suggests that for this group, the average years of education increased by 0.65 . This represents the first stage of the IV estimation. The instrument is quite strong, as the t-statistic for the instrument is nearly 100.

Columns 2-3 in Panel A of Table 5 show the results for mobility over 17 years. Interestingly, the OLS estimate in column 2 suggests that the less educated within this sample are more likely to move. This effect, of course, may be due to economic difficulties that induce mobility. However, the IV estimate suggests the causal effect of education on mobility is positive and statistically significant. At first glance, the estimated effect of education on the number of inter-county migrations (0.032, column 3) may seem modest, but not when one realises it compares to the average number of inter-county migrations of 0.21 over 17 years (see Table 4). A year of schooling thus increases regional rate of mobility by roughly $15 \%$. This constitutes a sizable and significant causal impact of education on mobility.

This difference in the OLS and IV results is evidently worth commenting on. The IV results provide a higher estimate of the effect of education on regional mobility than the OLS results in this case. This resembles the result often obtained in the returns to education where the returns are higher when instrumenting. The standard interpretation of this is that there is heterogeneity in returns, and that the instrument picks up the effect of a particular group with high returns since the IV has to be interpreted as a local average treatment effect (Card 1999, Aakvik, Salvanes and Vaage, 2008). This is a reasonable interpretation also in our case. We expect that the 
group affected by the mandatory school reform are those who would not voluntarily continue their schooling above the 7 years of mandatory education due to for instance budget constrains. As the 9 years were made mandatory and available in every municipality the level of schooling would increase in the relevant group. The increased education level makes them more mobile via many potential mechanisms such as having more information, or having obtained skills useful in the national labour market.

From Panel B of Table 5 one can also see that employment rates also significantly improve. The OLS estimate in column 2 suggests that one year of education would reduce years out of employment by 0.863 , which is a considerable effect given that on average, individuals on this sample are out of employment on average for 4.8 years over 17 years. The IV estimate suggests a smaller, but still sizeable estimate of 0.3 . This still corresponds to roughly $6 \%$ of all non-employment in the sample.

Columns 2 and 3 in Panel $\mathrm{C}$ of Table 5 could be considered "return to education” estimates for this low-educated sample of cohorts 1947-1958. The OLS estimates suggest a sizable return to education of $7.7 \%$, which is in line with relevant literature. The IV estimate is numerically a little lower at $7.4 \%$, but is very similar in terms of magnitude and not significantly different from the OLS estimate.

The last panel of Table 5 contains the results for the likelihood to be employed in a large town by 2002. Both the OLS and IV estimates suggest that education increases the likelihood of settling to a more central labour market of a major town.

The baseline results given in Table 5 therefore show a strongly significant positive causal impact of education on mobility. They also show that this goes handin-hand with improved labour market outcomes and so it seems that the positive 
education impact on mobility is likely to be linked to these improved employment and earnings opportunities that arise from increased education.

\subsection{Robustness checks}

It is important to probe further the identification assumptions underpinning these conclusions. Therefore as robustness checks we have run two falsification tests and estimated two alternative specifications.

First, we set up an 'imaginary' placebo experiment by pretending that the reform started three years earlier. We treat these three pre-reform cohorts as the new treatment group, which we compare to non-treated individuals in other municipalities. We use the same specification as in (1a)-(1b), and present the results in Table 6. The summary statistics of the sample are in the Appendix Table A3. Very reassuringly, the Table 6 results show there to be no effects to any of our outcomes, except to the likelihood to work in a large city which is unrealistically large, suggesting that unobservable trends within municipalities are not driving our results.

In the second falsification test, we test whether the reform increased mobility of the workers with more than 9 years of education. We very clearly find this not to be the case (see Table A4). We have run results separately for those with 10-12 years of education, and for those with 13 or more years of education. Note that the first stage of the IV is significant in the former group, suggesting that the school reform also increased intake at high-school level, but the test does not make us question our basic conclusions.

As the first alternative specification, we re-estimated the equations presented in Table 5, but additionally included parental education variables into the models. ${ }^{17}$

\footnotetext{
${ }^{17}$ In the case of Swedish comprehensive school reform, Holmlund (2007) shows that the IV-estimate of the return to education is affected depending whether parental education is controlled for. The summary statistics of parental education are in Table A6.
} 
This has only very minor effect on the results and the results are thus not shown. ${ }^{18}$ Secondly, we re-estimated the mobility effect of Panel A in Table 5 for the whole educational distribution. The results of the estimation are given in Table A7. The instrumental variable estimate for the whole educational distribution is still positive and statistically significant, and in fact is numerically larger than in Table 5, where the sample was restricted to the bottom of the education distribution. Thus it may actually be that restricting the sample results in a downward bias, as some of the people who benefited most from the reform by continuing to study further are excluded from the sample. This actually implies that, if anything, our baseline results may offer a lower bound on the causal impact of education.

\subsection{Panel data analysis}

The second empirical approach we adopt is to utilise the panel nature of the data to explore how education affects the annual rate of migration and the probability of being employed. We use a 17-year balanced panel dataset of 67,608 individuals born over 1947 to 1958 . As migration is defined by a change in the dependent variable from year $t$ to year $t+1$, we effectively have 16 observations per individual. Within this data, we have 11,230 incidences of inter-county migration. Summary statistics of the sample are shown in Table 7.

Modelling migration decisions can be complex, especially if one wishes to take into account all the possible destinations of migration (see e.g. Dahl, 2002). A simple theoretical framework with only one destination of migration is provided for example by Bentivogli and Pagano (1999). The authors use a two-period model of individual migration decisions to show that migration takes place if the expected utility from migration is larger than that from non-migration. In their model, this

\footnotetext{
${ }^{18}$ Key results were also estimated without people from Oslo, the capital, and it had little effect on the estimates.
} 
utility is a function of unemployment and income differences between home and destination, as well as income variance between the two regions, reflecting uncertainty.

In a similar vein to this approach, we adopt a simple, but flexible empirical strategy, in which we estimate the probability of migration as a function of year of migration, $D_{t}$, cohort, $D_{c}$, and education, using fixed effects, $\Omega_{m}$, for the municipality in which they had their schooling. Of these, we consider education to be endogenous, and instrument it with the school reform. The two equation system for the panel data models can be represented as:

$$
\begin{gathered}
\Delta \text { County }_{i t, t+1}=\alpha+\beta E d_{i}+\theta D_{\text {Female }}+\sum_{c} \lambda_{c} D_{c}+\sum_{t} \Psi_{t} D_{t}+\Omega_{m}+\varepsilon_{i t} \\
E d_{i}=\eta+\delta \text { Treated }_{i}+\varphi D_{\text {Female }}+\sum_{c} \psi_{c} D_{c}+\sum_{t} \pi_{t} D_{t}+\Omega_{m}+v_{i t}
\end{gathered}
$$

The first outcome we consider is the probability to migrate in any given year. Results for this dependent variable (in the equation (2a) specification) are presented in Table 8. The first column of Panel A repeats the first stage estimation of the IV model, but now using the full panel data set. In the sample that we are using, the annual migration rate is $1 \%$ (see Table 7 ), which is consistent with the fact that it refers to a low educated sample with an average age of 40 .

Columns 2-3 in Panel A provide estimates of the effect of education on the rate of migration, using both OLS and IV models. The estimated effect flips the sign from negative to positive as the IV is used. One year of education increases the rate of migration by 0.15 percentage points, which, when applied to sample mean, would mean a substantial increase from $1 \%$ per annum, to $1.15 \%$. The estimate corresponds to the $15 \%$ increase in the migration rate estimated in the life-cycle analysis above. 
Panel B of the Table 5 uses employment status in year $t$ as the dependent variable. The OLS estimate in column 2 suggests that education is strongly related to being employed. The point estimate 5 implies that one year of education translates to $5 \%$ higher probability of working. In the IV estimation, the result is still significant, but smaller. The causal effect suggested by the estimate if almost two percentage points (1.74\%). As a robustness check, we have run a similar falsification test as described in section 4.3. The results are given in the Appendix Tables A8 and A9. We find that the falsification test is passed. ${ }^{19}$

Overall, the results from the life-cycle analysis and the panel data analysis suggest there to be three clear effects: education increases wages, the likelihood of employment, and the rate of migration, from about $1 \%$ to $1.15 \%$ per year for this sample. Results by gender are presented in Appendix Tables A2 and A5 and are qualitatively similar, with some indication of slightly larger estimates for men.

\subsection{How does education affect mobility? Some possible channels}

The results presented above clearly show a significant positive education impact on mobility. But this finding, of course, raises the question about the channels via which education affects mobility. We have to date made connections with the labour market, but it is possible that other explanations also matter. For example, in addition to typical labour market explanations, one may speculate that staying in school for a longer period makes individuals postpone having children. It is possible for us to test for this, using analysis similar to the life-cycle analysis in section 4.1. We define the outcome to be the age of the person, when the first child is born (if it is born before 1986). The results are shown in Table 9. The OLS suggest that more educated have

\footnotetext{
${ }^{19}$ As a further robustness check to the mobility result, we included implementation year specific linear trends to the model, which had practically no effect on the size of the estimated coefficient.
} 
their first child slightly later, but the IV estimation does not support this. The results are similar for both genders (not shown separately). ${ }^{20}$

In our view, this leaves the labour market explanation as the strongest candidate for the main results. It may be that mobility is a function of job offers, and that employers have had a preference for those workers who have gone through the new school system. One has to keep in mind that for these workers, having gone through the new system will not be a signal of motivation, since it is still the lowest attainment. Therefore, if the employers are willing to pay higher wages to the workers from the new school system, there should be a skill related reason to it.

4.6 Are the results explained by general equilibrium effects?

The mobility results could also in principle be explained by general equilibrium effects in the labour market. Increased supply of education in early reforming municipalities could lead to relatively higher returns to education in those municipalities that reform later. This then could cause workers from early reforming municipalities to migrate to late reforming ones. If this were true, the policy implications of the mobility result of this paper would be rendered weaker, since simultaneous increase of education level across the country would not necessarily lead to higher mobility. We therefore test for possible general equilibrium effects by considering whether the workers who gained in education due to the reform are more likely to move to municipalities that reformed late.

To test the hypothesis in a simple way, we use adopt an estimation approach similar to that in Panel D of Table 5, except that we replace dependent variable from 'large town' to late reforming municipalities, defined as ones that started their reform from birth cohort 1953, or later. The results are given in Table 10. The OLS

\footnotetext{
${ }^{20}$ Black, Devereux and Salvanes (2008) find a reduction in becoming teenage mothers in Norway and the US of increased education, and Monstad, Propper and Salvanes (2008) only find modest changes on fertility decisions of increased education for women.
} 
estimation suggests that more educated are less likely to end up living in a late reforming municipality by 2002. The IV estimate on the other hand reveals no connection between years of education and the likelihood of settling into a latereforming municipality, where there supposedly is a relative shortage of skills. This suggests that the mobility induced by the school reform is not driven by workers moving from early reforming municipalities to late reforming ones in the prospect of maximising the value of their human capital.

\subsection{Age specific effects}

As noted above, regional mobility of people varies considerably by age. In this section, we run the analysis for different age groups to see at what parts of age distribution are the effects largest. Figure 7 suggests that largest differences in mobility by education occur when people are in 20s or 30s.

In the panel data that we have constructed, age specific effects of education can be studied, since each individual is observed several times. The estimation requires restricting the sample by age, and controlling for birth cohorts. In Table A10, we have split the sample to three groups that span 9 years, and estimated a linear IV model for the probability to migrate.

We find that the probability to migrate is affected by education more strongly in the oldest and youngest age groups. The age specific results may be complex to interpret, but the signs of the estimates are the same for all age groups, and this suggests that the inferences we have made about the directions of the effects are both correct and robust. 


\section{Conclusions}

Many commentators express the view that lack of education hinders the kind of mobility that modern labour markets need to function efficiently. However, at the moment there is not much evidence that can be brought to bear to support this contention. In this paper we have studied connections between education levels and labour mobility, pinning down the causal impact of education. When focusing on the lowest levels of educational attainment our estimates show that one additional year of education can cause a significant increase in the likelihood of regional mobility.

The magnitudes of the estimates show that one year of education increases the annual mobility rates by 15 percent from a low base rate of $1 \%$ per year for the sample used in this study. The extent to which this rate of increase can be applied to the general population remains unclear but, in terms of policy, it is important to make the point that the segment of the population with lowest educational attainment is arguably the most interesting one. This is certainly the case when commentators highlight labour market problems by appealing to problems of low mobility amongst the less educated or skilled.

We also showed that the results are not driven by fertility decisions - the people treated by the school reform have their first children on average at the same age as those who went to a shorter compulsory schooling. This leaves a human capital explanation as the most appealing explanation for the mobility, and labour market success of the individuals who have had to stay in school longer.

Lower mobility rates of less educated workers have been shown to be a common, if not universal phenomenon, and cross country data confirms a strong correlation between regional mobility and education. Our results suggest these patterns are causal for the groups with lowest levels of educational attainment. 
Importantly, this implies that educational interventions that increase years of schooling could help bridge some of the differences in the dynamism and labour market efficiency between countries characterised by differing rates of labour mobility. 


\section{References}

Aakvik A., Salvanes K.G. and Vaage K. (2008). Measuring Heterogeneity in the Returns to Education in Norway Using Educational Reforms. CEPR discussion paper no. 4088. Forthcoming in the European Economic Review.

Antolin P. and Bover O. (1997). Regional migration in Spain: the effect of personal characteristics and of unemployment, wage and house price differentials using pooled cross-sections. Oxford Bulletin of Economics and Statistics, 59, 21535.

Baddeley M., Martin R. and Tyler P. (1998). European Regional Unemployment Disparities: Convergence or Persistence? European Urban and Regional Studies, July 1, 1998, 5(3), pp. 195-215.

Barro R. and Lee J.W. (2001). International Measures of Schooling Years and Schooling Quality. American Economic Review, Papers and Proceedings, 86(2), pp. 218-223

Belot M. and Ederveen J.P. (2005). Cultural and Institutional Barriers in International Migration Between OECD Countries. Mimeo.

Belot M. (2007). Why is Employment Protection Stricter in Europe than in the United States? Economica, 74 (295), pp. 397-423

Bentivogli C. and Pagano P. (1999). Regional Disparities and Labour Mobility: the Euro-11 versus the USA. Labour, vol. 13 (3), pp. 737-760.

Black S., Devereux P. and Salvanes K.G. (2005). Why the apple doesn't fall far: Understanding Intergenerational Transmission of Human Capital. The American Economic Review, Vol. 95 (1), 437-449.

Black, S., P. Devereux and K.G. Salvanes (2008). Staying in the classroom and out of the maternity ward? The effect of compulsory schooling laws on teenage births. The Economic Journal, vol. 118 (July), pp.1025-1954.

Blanchard J. O. and Katz L. F. (1992). Regional Evolutions. Brookings Papers on Economic Activity, vol. 1992, no. 1, pp. 1-75.

Card, D. (1999). The Causal Effect of Education on Earnings. In: Orley Ashenfelter and David Card (eds.), Handbook of Labor Economics Volume 3A. Amsterdam: Elsevier, 1999.

Dahl G. B. (2002). Mobility and the Return to Education: Testing a Roy Model with Multiple Markets. Econometrica, vol.70, No. 6, pp. 2367-2420.

David Q., Janiak A. and Wasmer E. (2008a). Local Social Capital and Geographic Mobility - A Theory. IZA Discussion Paper no.3668.

David Q., Janiak A. and Wasmer E. (2008b). Local Social Capital and Geographic Mobility - Some Empirics and a Conjecture on the Nature of European Unemployment. IZA Discussion Paper no.3669.

Decressin J. and Fatas, D. (1995). Regional Labor Market Dynamics in Europe. European Economic Review, vol. 39, pp. 1627-1655.

Eurobarometer (2001a) Special Survey 54.2. Social Situation in the European Union. February 2001.

Eurobarometer (2001b) Standard survey 54. April 2001.

Gregg, P., S. Machin and A. Manning (2004). Mobility and Joblessness. In R. Blundell, D. Card and R. Freeman (eds) Seeking a Premier League Economy, NBER.

Holmlund H. (2007). A Researcher's Guide to the Swedish Compulsory School Reform. Swedish Institute for Social Research Working Paper 9/2007. 
Huber P. (2004). Inter-regional mobility in Europe: a note on the cross-country evidence. Applied Economics Letters, Volume 11, Number 10, August 15, 2004 , pp. 619-624(6)a

Hughes G.A. and McCormick B. (1987). Housing Markets, Unemployment and Labour Market Flexibility in the UK. European Economic Review, 31, 615-65.

Hughes G.A. and McCormick B. (1994). Is Migration in the 1980s Narrowing the North-South Divide? Economica, pp 509-527.

Leschinsky A. and Mayer K.U., eds. (1990). The comprehensive school experiment revisited: Evidence from Western Europe. Frankfurt am Main: Verlag Peter Lang, 1990.

Lie S. S. (1973). Regulated Social Change: A Diffusion Study of The Norwegian Comprehensive School Reform. Acta Sociologica, 16(4), 332-350.

Lindbekk, T. (1993). School Reforms in Norway and Sweden, and the Redistributions of Educational Attainments. Scandinavian Journal of Educational Research, vol. 37(2), pp.129-149.

Malamud, O. and Wozniak A. (2008). The Impact of College Graduation on Geographic Mobility: Identifying Education Using Multiple Components of Vietnam Draft Risk. IZA Discussion Paper no.3432.

McCormick B. (1997). Regional Unemployment and Labour Mobility in the UK. European Economic Review, vol. 41, pp. 581-589.

Meghir, C. and Palme, M. (2005). Educational Reform, Ability, and Parental Background. American Economic Review, 95 (1), 414-424.

Monstad, K., C. Propper, and K.G. Salvanes (2008). Education and Fertility: Evidence from a Natural Experience. Forthcoming Scandinavian Journal of Economics.

Møen J., Salvanes K.G. and Sørensen E. Ø. (2004). Documentation of the Linked Employer-Employee Data Base at the Norwegian School of Economics. Mimeo, Norwegian School of Economics and Business Administration.

OECD (1986). Flexibility in the Labour Market. Paris: OECD.

Oswald A. (1999). The Housing Market and Europe’s Unemployment. Manuscript, University of Warwick.

Ness E. (ed.) (1971). Skolens Årbok 1971. Olso: Johan Grundt Tanum Forlag. (In Norwegian)

Pekkarinen T., Uusitalo, R. and Pekkala S. (2006). Education Policy and Intergenerational Income Mobility: Evidence from the Finnish Comprehensive School Reform. IZA Discussion Paper no. 2204.

Spilimbergo A. And Ubeda L. (2002). A Model of Multiple Equilibria in a Model of Labour Mobility. IMF Working Paper 02/31.

Statistics Norway (1998). Labour Market Survey.

US Census Bureau. (1986). Current Population Survey. Population Characteristics, Series P-20, No. 407. Geographical Mobility: March 1983 to March 1984.

US Census Bureau. (1997). Current Population Survey. Population Characteristics, Series P-20, No. 497. Geographical Mobility: March 1995 to March 1996.

Viarengo, M. (2007). An Historical Analysis of the Expansion of Compulsory Schooling in Europe after the Second World War. Working paper 97/07, Department of Economic History, London School of Economics. 
Figure 1 Years of education and regional mobility

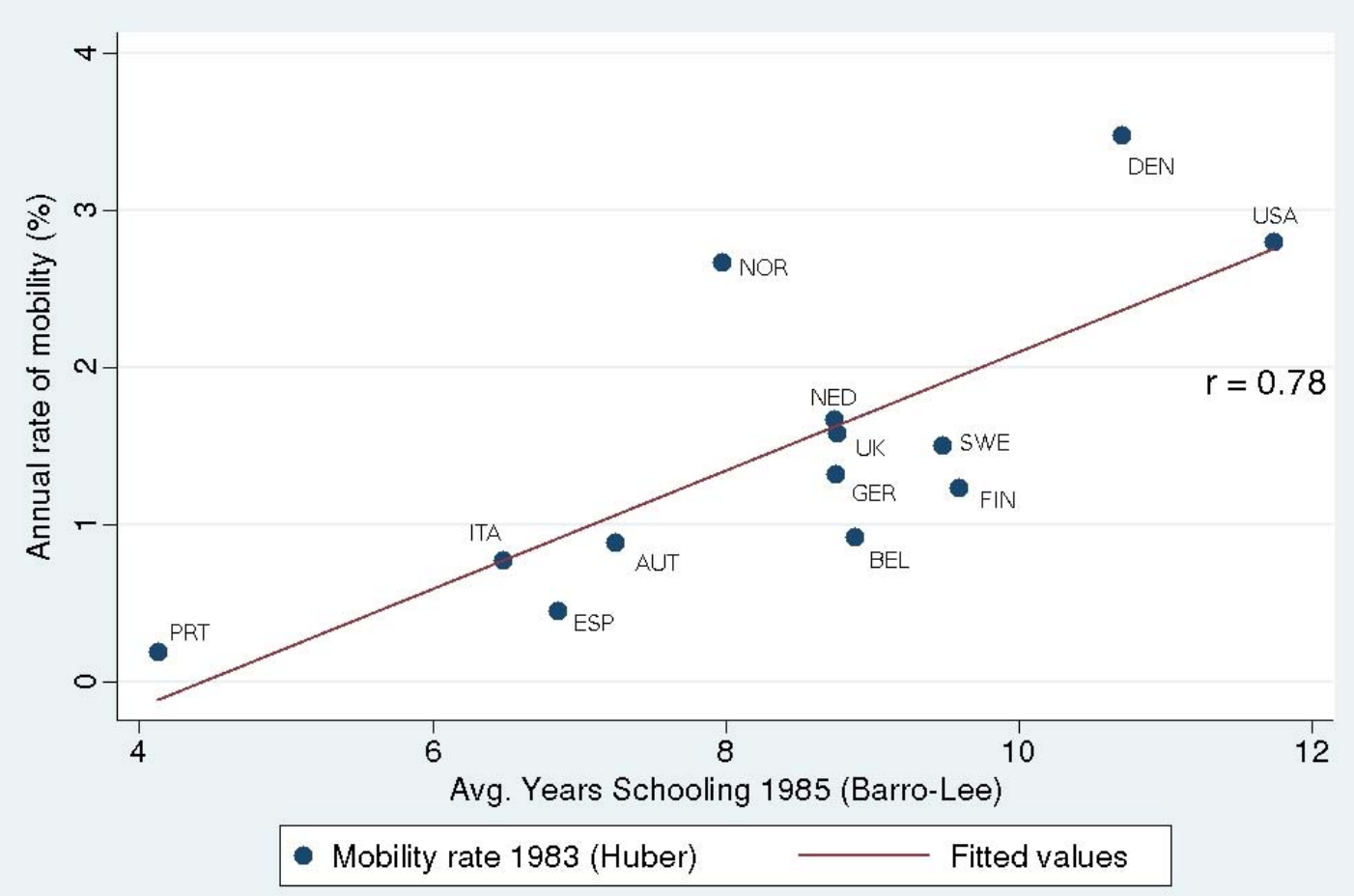

Figure 2 Years of education and the proportion of population that has moved house within the last 10 years

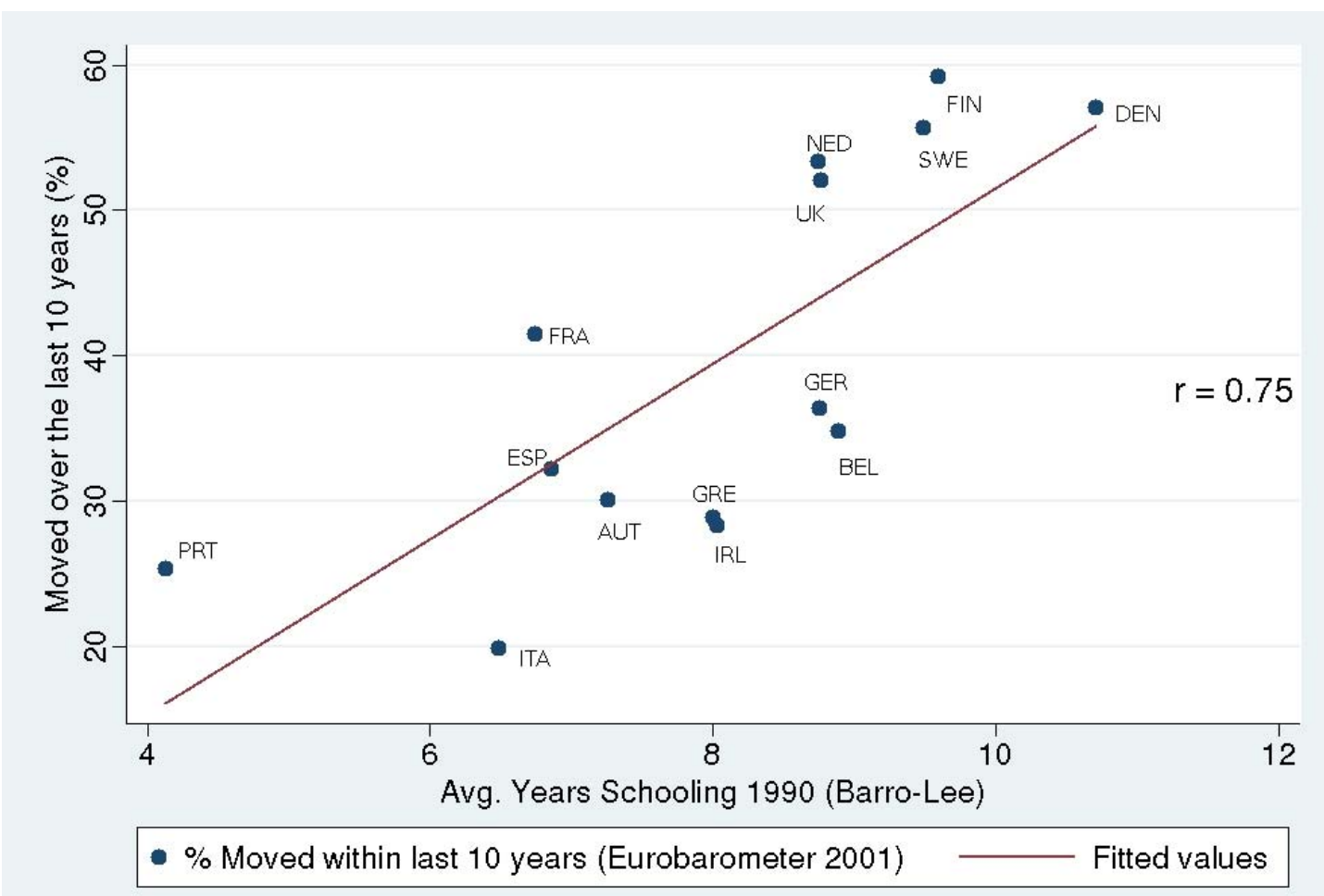


Figure 3 Years of education and the \% of population claiming not to be attached to his/her own town/village

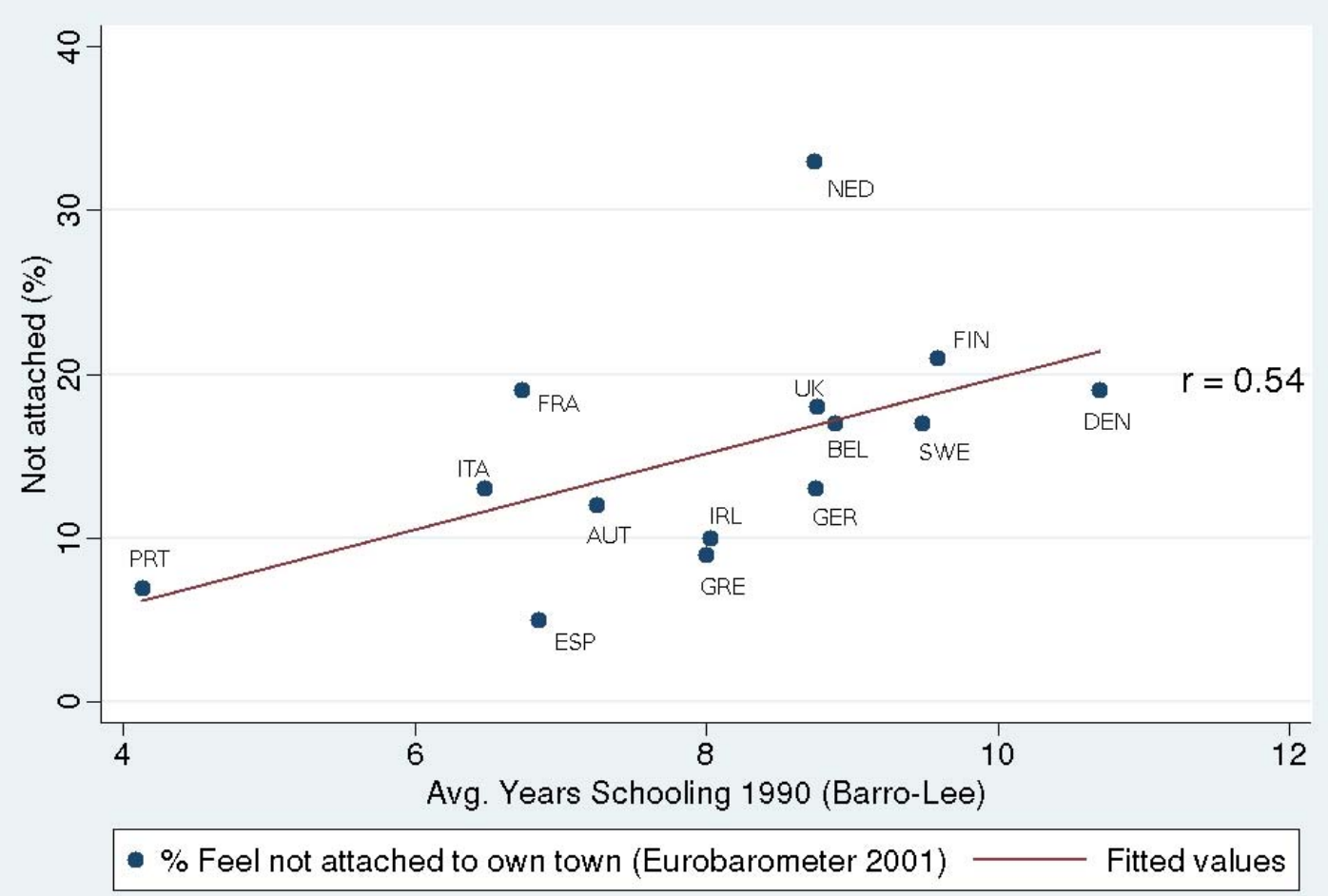

Figure 4 The proportion of the Norwegian labour force (20-64) by education

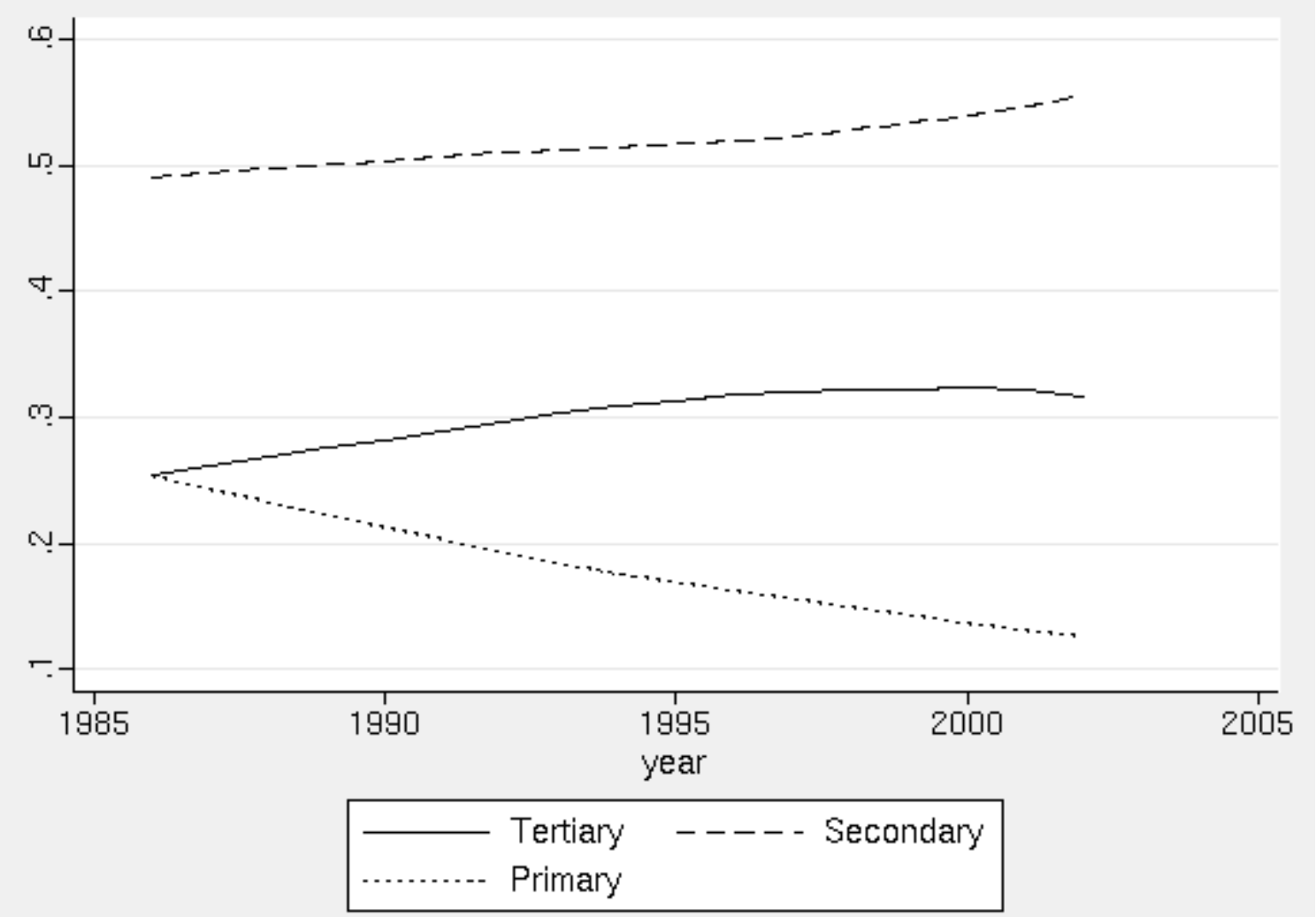


Figure 5 Employment rates of Norwegian men by age and education level

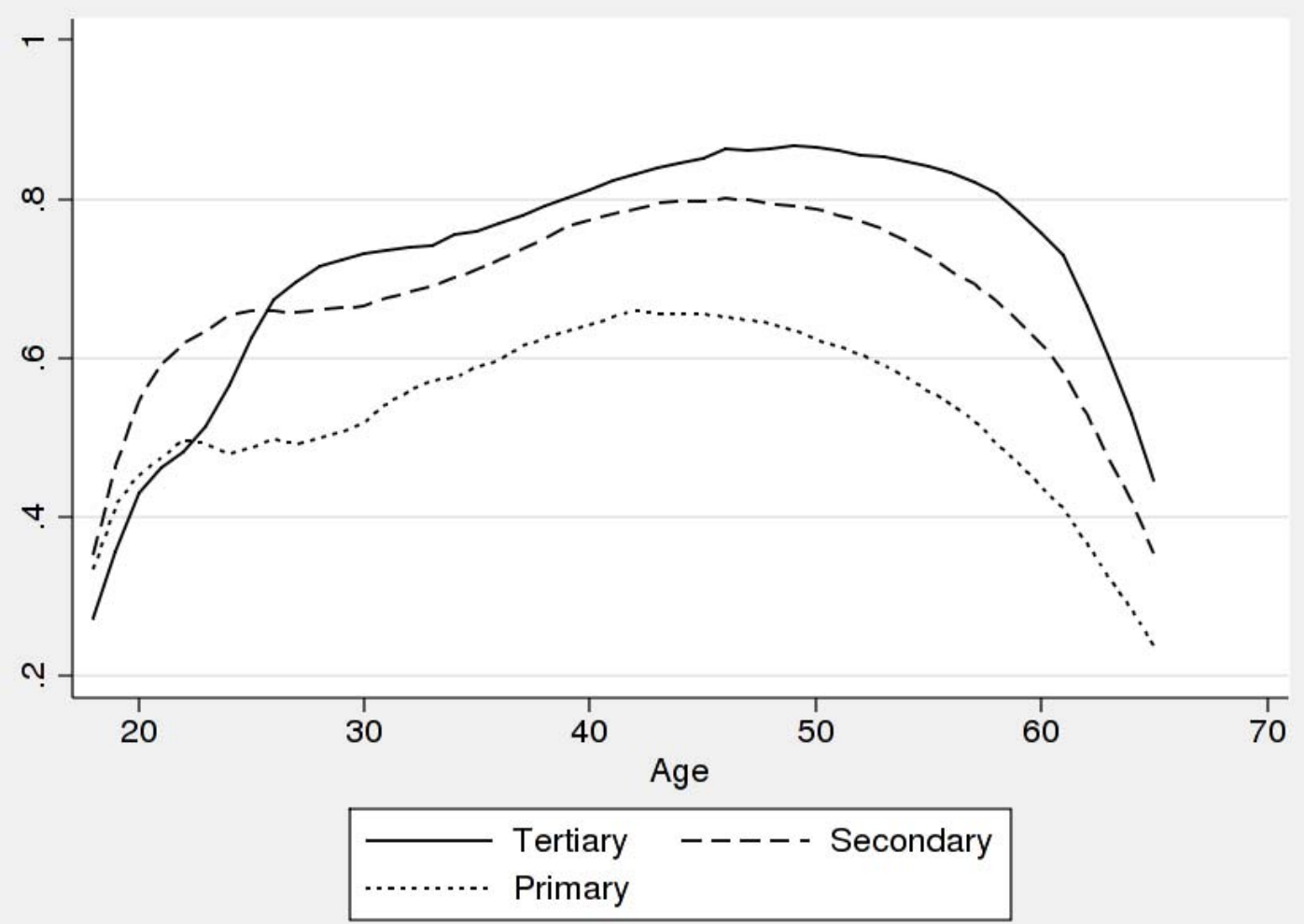

Figure 6A Employment rates of workers with primary education, across 19 Norwegian counties and 17 years

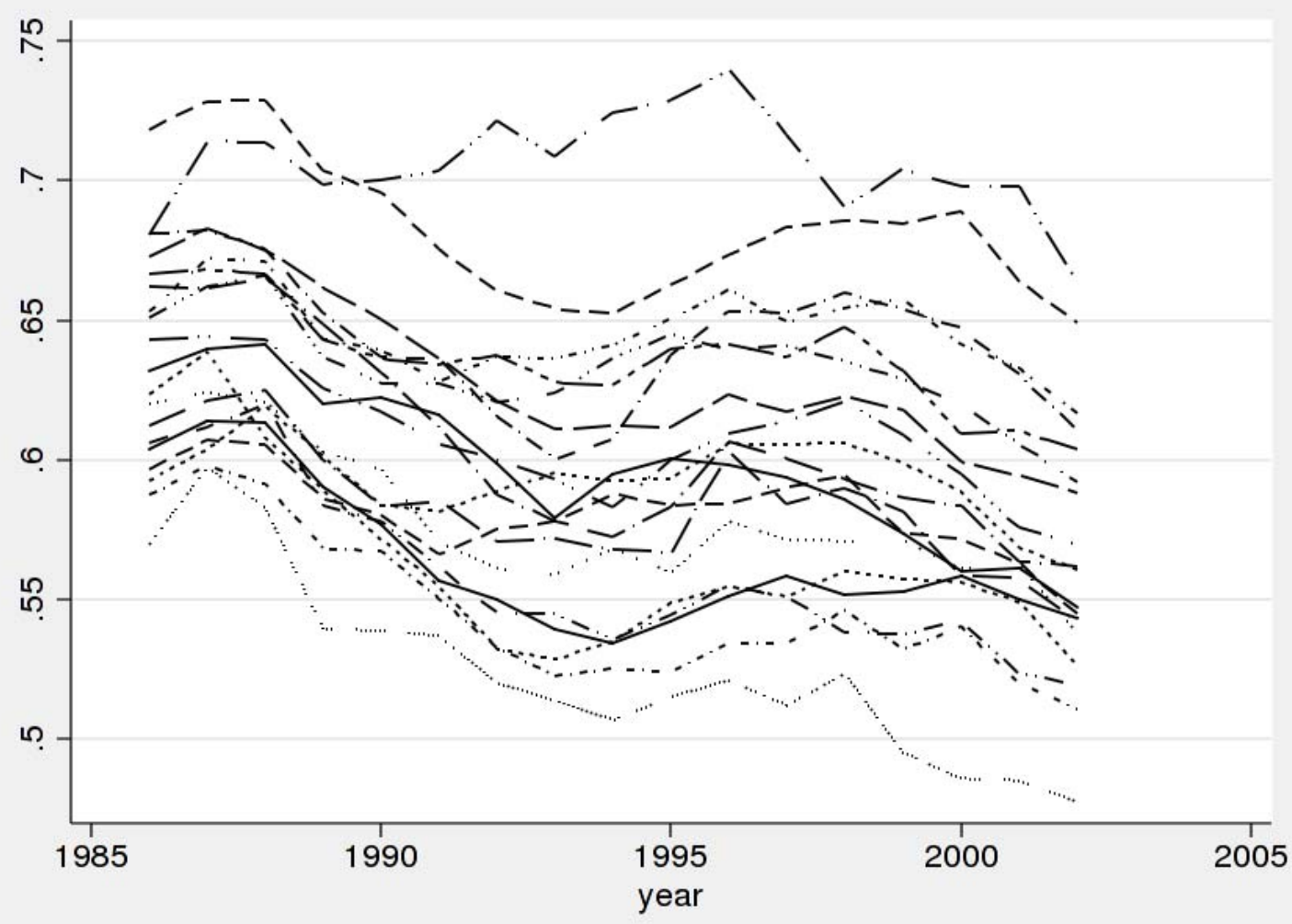


Figure 6B Employment rates of workers with secondary education, across 19 Norwegian counties and 17 years

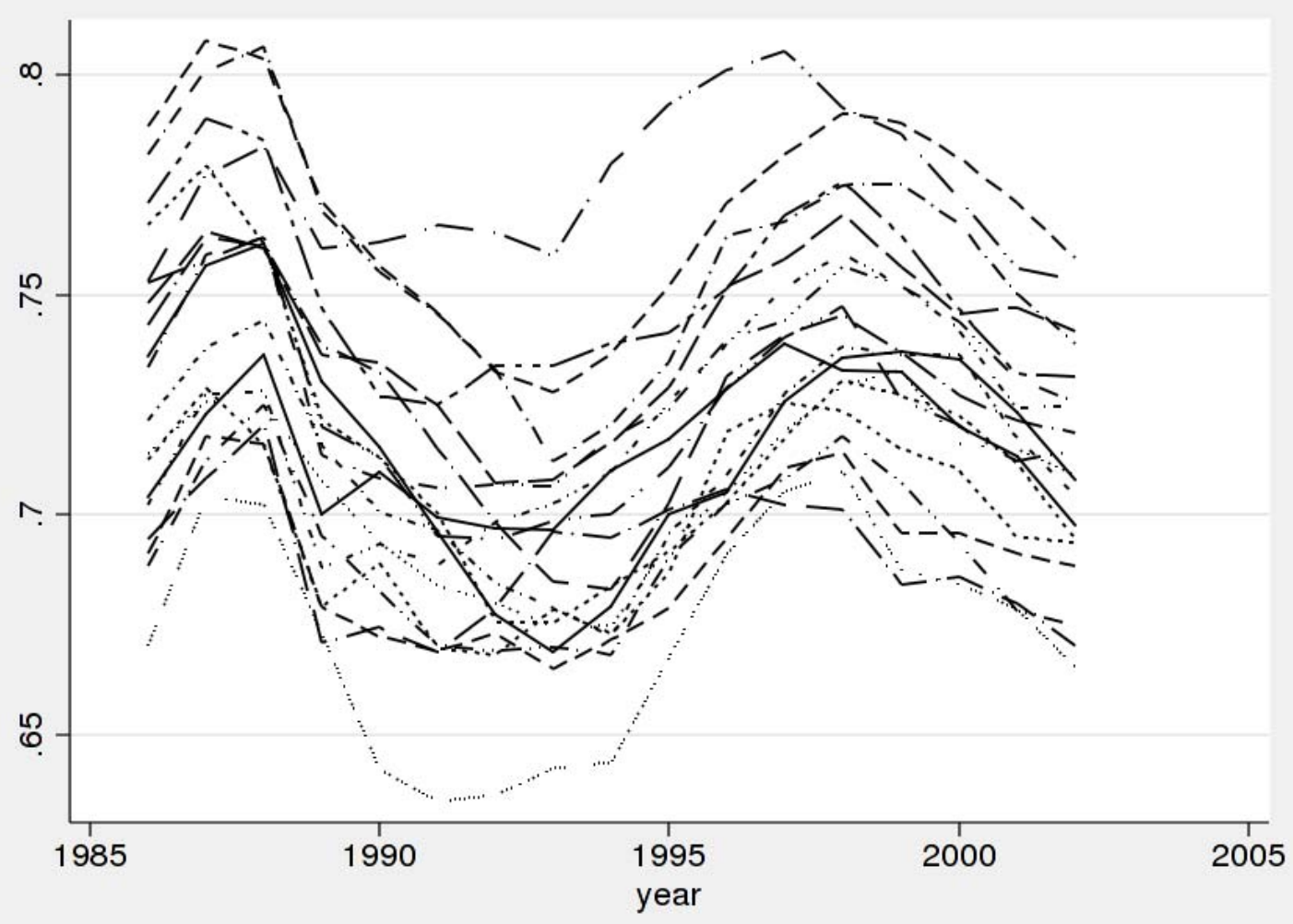

Figure 6C Employment rates of workers with tertiary education, across 19 Norwegian counties and 17 years

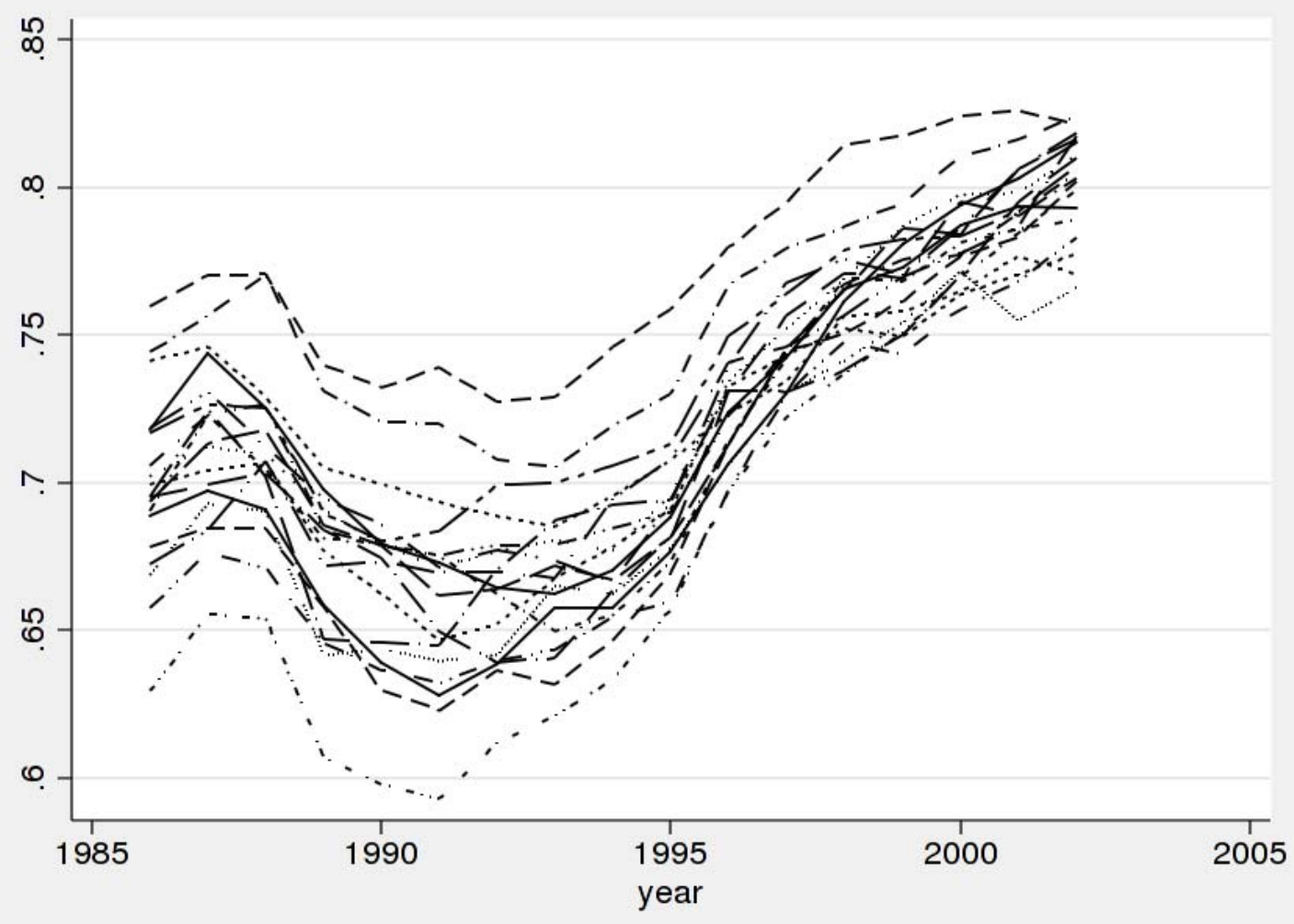


Figure 7 Migration rates of Norwegian men by age and education level

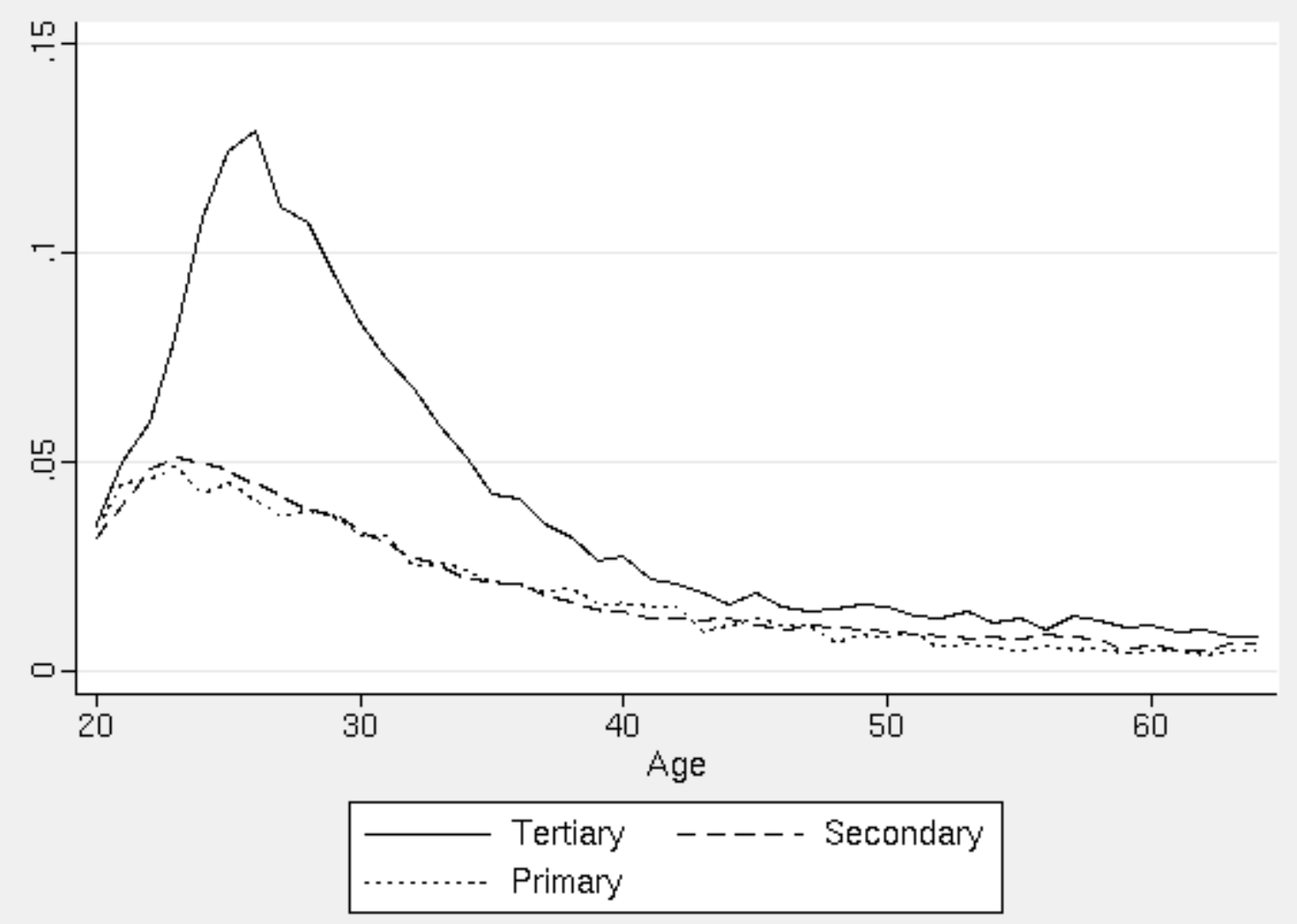


Figure 8 Timing of the reform across Norwegian municipalities, by the first affected birth cohort

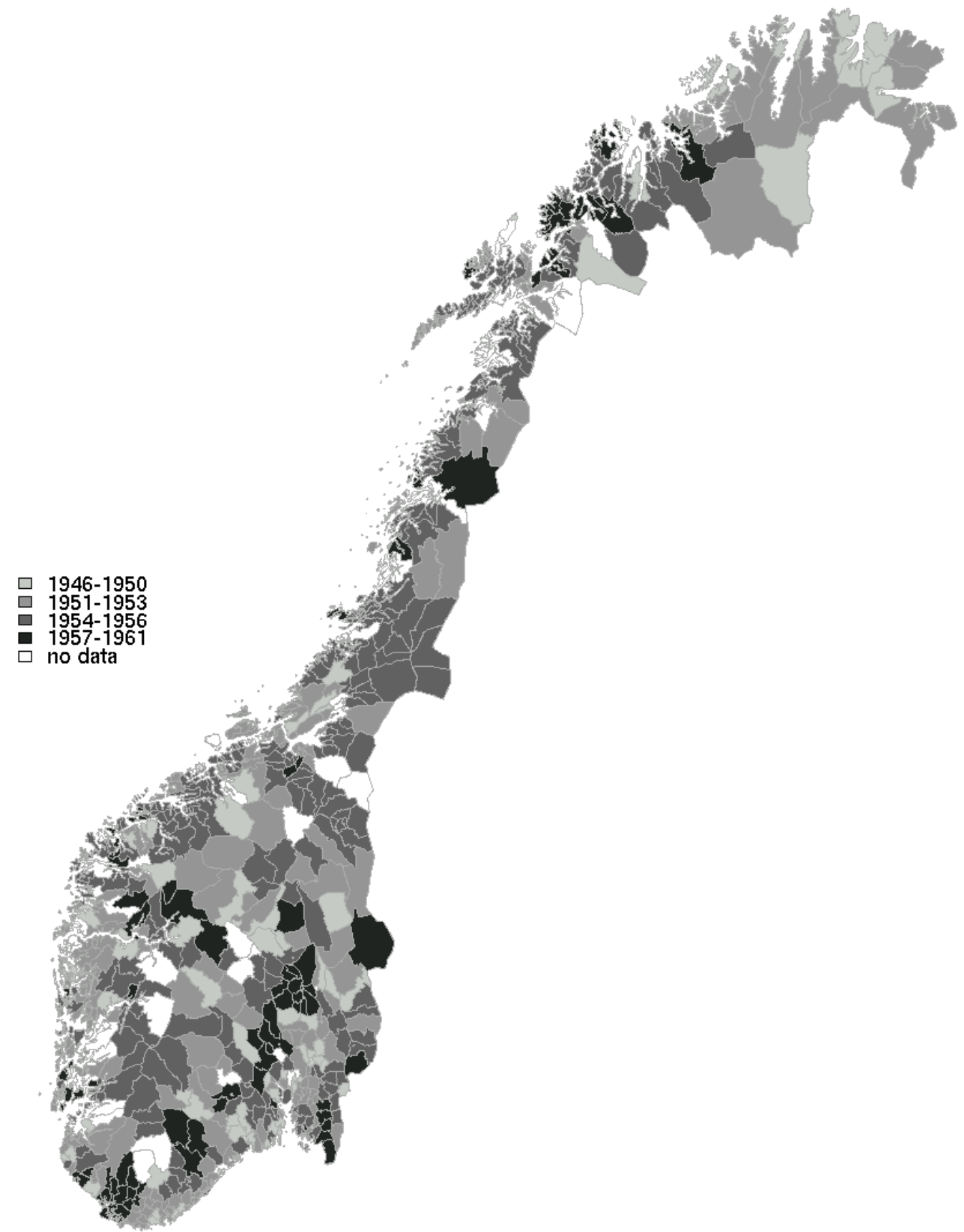


Figure 9 The impact of the school reform on years of schooling

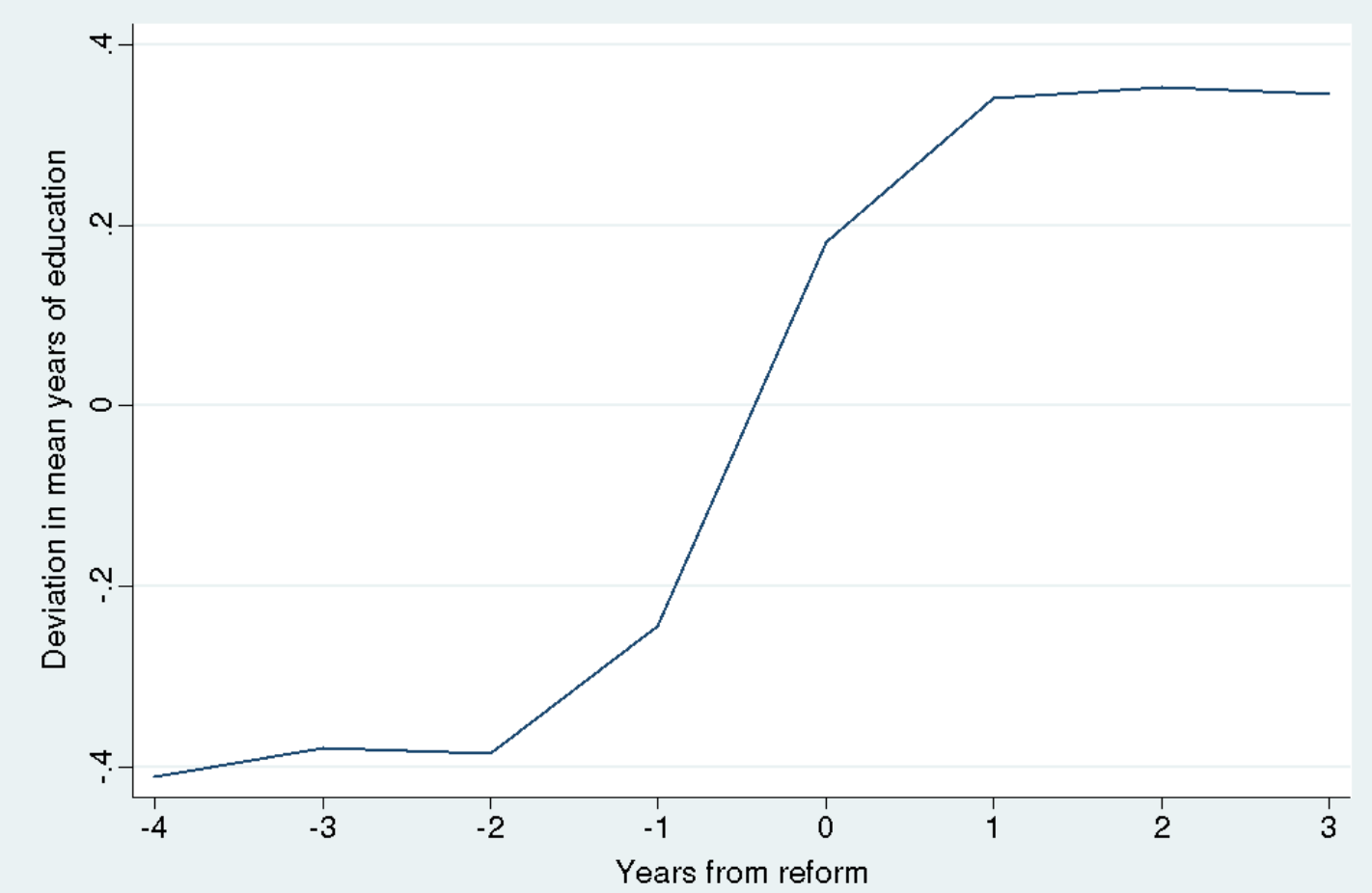

Notes: Based on 67608 individuals and a model where years of education is predicted with municipality and cohort effects as well as dummies which correspond to years from the initiation of the reform. The effects of these dummies are plotted on the table. 


\section{Table 1 Employment transition matrices by mobility status}

Non-migrants

$(97 \%)$

Year $\mathbf{t}+1$

\begin{tabular}{l|cc|} 
Year t & Not Employed & Employed \\
\cline { 2 - 3 } Not Employed & $22 \%$ & $7 \%$ \\
Employed & $6 \%$ & $65 \%$ \\
\cline { 2 - 3 } & & $\mathrm{N}=4106023$
\end{tabular}

Migrants

(3\%)

Year t

Year $\mathbf{t}+1$

Not Employed

Employed

Based on a 10\% random sample of the whole working age population (18-65) over 1986-2002 Mobility is defined as inter-county migration. Norway has 19 mainland counties.

Table 2 'Exogeneity' of the school reform (municipality level)

\begin{tabular}{lcc}
\hline Dependent: & \multicolumn{1}{c}{ Birth year of the first reformed cohort } \\
\hline & $(1)$ & $(2)$ \\
\hline ln Income & & $-2.265(1.356)$ \\
ln Income dispersion & $-1.010(1.546)$ & $1.689(1.042)$ \\
\% Tertiary education & $1.432(1.033)$ & $-12.128(15.088)$ \\
\% Secondary education & $-2.912(15.666)$ & $9.082(8.848)$ \\
\% Primary education & $3.245(9.245)$ & $.054(2.096)$ \\
\% working in Services & $-.395(2.151)$ & $-2.436(4.052)$ \\
\% working in Manufacturing & $-2.425(4.530)$ & $1.524(3.282)$ \\
\% out of labour force & $-.095(3.564)$ & $.607(8.405)$ \\
\% Married at least once & $-5.714(8.584)$ & $-.806(5.568)$ \\
Log Municipal population & $-4.357(6.355)$ & $-.023(.168)$ \\
\% voting for the Labour party & $-.077(.180)$ & $-.274(.740)$ \\
\% voting for the Centre party & $.238(.807)$ & $-.045(.825)$ \\
\% voting for the Conservatives & $.093(.817)$ & $-2.427(1.509)$ \\
\% voting for the Communist party & $-1.031(1.718)$ & $-3.325(2.607)$ \\
\% voting for the Christian people’s party & $.502(2.907)$ & $-.925(1.346)$ \\
Voter turnout & $-1.095(1.374)$ & $-1.246(1.431)$ \\
\% in ages 0-17 & $-.345(1.513)$ & $3.131(7.002)$ \\
\% in ages 18-34 & $-3.529(7.274)$ & $9.790(9.260)$ \\
\% in ages 35-64 & $4.704(9.510)$ & $22.554(10.684)$ \\
Constant & $16.246(10.631)$ & $1,949.714(16.624)$ \\
County Dummies & $1,948.683(17.274)$ & 0.06 \\
Observations & Yes & \\
R-squared & 650 & \\
& 0.16 & \\
\hline
\end{tabular}

Notes: All explanatory variables are aggregated from the 1960 census, except for the electoral results and turnout, which are from 1959 elections, and income data, which is from 1967. The ln Mean Income is calculated for males aged 20-65. The Income dispersion measure refers to difference between $90^{\text {th }}$ and $10^{\text {th }}$ percentile of the in the same group, within municipalities. 
Table 3 Impact of reform on educational attainment

(final educational attainment in 2002)

\begin{tabular}{|c|c|c|c|}
\hline \multicolumn{4}{|c|}{$\begin{array}{l}\text { A. Cohorts } 1947-1958- \\
\text { (490055 people aged } 44-55 \text { in } 2002)\end{array}$} \\
\hline Years of Education & Before Reform & After Reform & Change (S.E.) \\
\hline 7 & .036 & .005 & $-.031(.000)$ \\
\hline 8 & .099 & .008 & $-.091(.001)$ \\
\hline 9 & .021 & .116 & $.095(.001)$ \\
\hline 10 & .285 & .255 & $-.030(.001)$ \\
\hline 11 & .086 & .090 & $.004(.001)$ \\
\hline 12 & .177 & .217 & $.040(.001)$ \\
\hline 13 & .065 & .058 & $-.007(.001)$ \\
\hline 14 & .053 & .060 & $.007(.001)$ \\
\hline 15 & .025 & .042 & $.017(.001)$ \\
\hline $16+$ & .153 & .147 & $-.006(.001)$ \\
\hline \multicolumn{4}{|c|}{$\begin{array}{l}\text { B. Cohorts 1952-1954 } \\
\text { (138131 people aged } 48-50 \text { in 2002) }\end{array}$} \\
\hline Years of Education & Before Reform & After Reform & Change (S.E.) \\
\hline 7 & .027 & .009 & $-.018(.001)$ \\
\hline 8 & .089 & .011 & $-.078(.001)$ \\
\hline 9 & .026 & .126 & $.100(.001)$ \\
\hline 10 & .295 & .263 & $-.032(.002)$ \\
\hline 11 & .095 & .089 & $-.006(.002)$ \\
\hline 12 & .176 & .189 & $.013(.002)$ \\
\hline 13 & .063 & .063 & $.000(.001)$ \\
\hline 14 & .054 & .060 & .006 (.001) \\
\hline 15 & .030 & .032 & $.002(.001)$ \\
\hline $16+$ & .148 & .159 & $.011(.002)$ \\
\hline
\end{tabular}

Table 4 Summary statistics for 1947-1958 birth cohorts with nine or less years of education (and treatment status is known)

Mean (Standard deviation)

Education Variables

Affected by reform (Treated)

Years of education by 2002

\section{Outcomes}

Number of inter-county migrations

$.21(.64)$

Years not employed (out of 17)

$4.787(5.541)$

Earnings in 1998 (NOK)

$174,559(136,239)$

Employed in one of 9 largest towns by 2002

$.19(.39)$

Notes: Based on 67608 people with nine or less years of education in birth cohorts born between 1947 and 1958. The 9 largest towns are Oslo, Bergen, Trondheim, Stavanger, Tromsø, Fredrikstad, Bærum, Drammen and Kristiansand. 
Table 5 The causal effect of education on mobility, earnings and town size

\begin{tabular}{|c|c|c|c|}
\hline \multicolumn{4}{|c|}{ A. Mobility and Education } \\
\hline Dependent Variable: & $\begin{array}{c}\text { Years of } \\
\text { Education }\end{array}$ & \multicolumn{2}{|c|}{ Number inter-county migrations } \\
\hline Estimator: & $\begin{array}{c}1^{\text {st }} \text { Stage } \\
\text { OLS }\end{array}$ & OLS & IV \\
\hline Affected by Reform & $.650(.008)$ & & \\
\hline Years of Education & & $-.022(.005)$ & $.032(.013)$ \\
\hline Female & $.052(.004)$ & $-.039(.005)$ & $-.042(.005)$ \\
\hline Sample Size & 67608 & 67608 & 67608 \\
\hline R-squared & .41 & .01 & \\
\hline \multicolumn{4}{|c|}{ B. Employment and Education } \\
\hline Dependent Variable: & $\begin{array}{l}\text { Years of } \\
\text { Education }\end{array}$ & \multicolumn{2}{|c|}{ Years not employed (out of 17) } \\
\hline Estimator: & $\begin{array}{c}1^{\text {st }} \text { Stage } \\
\text { OLS }\end{array}$ & OLS & IV \\
\hline Affected by Reform & $.650(.008)$ & & \\
\hline Years of Education & & $-.863(.042)$ & $-.300(.112)$ \\
\hline Female & $.052(.004)$ & $2.705(.042)$ & $2.674(.043)$ \\
\hline Sample Size & 67608 & 67608 & 67608 \\
\hline R-squared & .41 & .06 & \\
\hline \multicolumn{4}{|c|}{ C. Earnings and Education } \\
\hline Dependent Variable: & $\begin{array}{c}\text { Years of } \\
\text { Education }\end{array}$ & \multicolumn{2}{|c|}{ Log(Earnings), 1998} \\
\hline Estimator: & $\begin{array}{c}1^{\text {st }} \text { Stage } \\
\text { OLS }\end{array}$ & OLS & IV \\
\hline Affected by Reform & $.650(.008)$ & & \\
\hline Years of Education & & $.077(.008)$ & $.074(.021)$ \\
\hline Female & $.052(.004)$ & $-.555(.008)$ & $-.555(.008)$ \\
\hline Sample Size & 67608 & 56562 & 56562 \\
\hline R-squared & .41 & .08 & \\
\hline \multicolumn{4}{|c|}{ D. Employed in Large Town and Education } \\
\hline Dependent Variable: & $\begin{array}{c}\text { Years of } \\
\text { Education }\end{array}$ & Employed ir & ns by 2002 \\
\hline Estimator: & $\begin{array}{c}1^{\text {st }} \text { Stage } \\
\text { OLS }\end{array}$ & OLS & IV \\
\hline Affected by Reform & $.650(.008)$ & & \\
\hline Years of Education & & $.025(.004)$ & $.015(.007)$ \\
\hline Female & $.052(.004)$ & $-.024(.004)$ & $-.024(.004)$ \\
\hline Sample Size & 67608 & 67608 & 67608 \\
\hline R-squared & .41 & .01 & \\
\hline
\end{tabular}

Notes: Individuals with 9 or less years of education and known treatment status. All models control for year dummies and the municipality of growing up. Standard errors in parentheses are corrected for heteroscedasticity. 
Table 6 Falsification exercise: The causal effect of education on mobility, earnings and town size

\begin{tabular}{|c|c|c|c|}
\hline \multicolumn{4}{|c|}{ A. Mobility and Education } \\
\hline $\begin{array}{l}\text { Dependent } \\
\text { Variable: }\end{array}$ & $\begin{array}{c}\text { Years of } \\
\text { Education }\end{array}$ & \multicolumn{2}{|c|}{ Number inter-county migrations } \\
\hline Estimator: & $\begin{array}{l}1^{\text {st }} \text { Stage } \\
\text { OLS }\end{array}$ & IV & Reduced form \\
\hline $\begin{array}{l}\text { ‘Affected’ by } \\
\text { Imaginary Reform }\end{array}$ & $.050(.010)$ & & $-.003(.011)$ \\
\hline $\begin{array}{l}\text { Years of Education } \\
\text { Female }\end{array}$ & $.083(.006)$ & $\begin{array}{l}-.065(.216) \\
-.020(.019)\end{array}$ & $-.042(.005)$ \\
\hline $\begin{array}{l}\text { Sample Size } \\
\text { R-squared }\end{array}$ & $\begin{array}{l}32509 \\
.06\end{array}$ & 32509 & $\begin{array}{c}32509 \\
.00\end{array}$ \\
\hline \multicolumn{4}{|c|}{ B. Employment and Education } \\
\hline $\begin{array}{l}\text { Dependent } \\
\text { Variable: }\end{array}$ & $\begin{array}{c}\text { Years of } \\
\text { Education }\end{array}$ & \multicolumn{2}{|c|}{ Years not employed (out of 17) } \\
\hline Estimator: & $\begin{array}{l}1^{\text {st }} \text { Stage } \\
\text { OLS }\end{array}$ & IV & Reduced form \\
\hline $\begin{array}{l}\text { ‘Affected’ by } \\
\text { Imaginary Reform }\end{array}$ & $.050(.010)$ & & $.002(.107)$ \\
\hline $\begin{array}{l}\text { Years of Education } \\
\text { Female }\end{array}$ & $.083(.006)$ & $\begin{array}{l}.036(2.123) \\
2.629(.187)\end{array}$ & $2.632(.063)$ \\
\hline $\begin{array}{l}\text { Sample Size } \\
\text { R-squared }\end{array}$ & $\begin{array}{c}32509 \\
.06\end{array}$ & 32509 & $\begin{array}{c}32509 \\
.06\end{array}$ \\
\hline \multicolumn{4}{|c|}{ C. Earnings and Education } \\
\hline $\begin{array}{l}\text { Dependent } \\
\text { Variable: }\end{array}$ & $\begin{array}{c}\text { Years of } \\
\text { Education }\end{array}$ & \multicolumn{2}{|c|}{ Log(Earnings), 1998} \\
\hline Estimator: & $\begin{array}{l}1^{\text {st }} \text { Stage } \\
\text { OLS }\end{array}$ & IV & Reduced form \\
\hline $\begin{array}{l}\text { ‘Affected’ by } \\
\text { Imaginary Reform }\end{array}$ & $.050(.010)$ & & $.006(.020)$ \\
\hline $\begin{array}{l}\text { Years of Education } \\
\text { Female }\end{array}$ & $.083(.006)$ & $\begin{array}{l}.128(.434) \\
-.559(.039)\end{array}$ & $-.548(.012)$ \\
\hline $\begin{array}{l}\text { Sample Size } \\
\text { R-squared }\end{array}$ & $\begin{array}{l}32509 \\
.06\end{array}$ & 27061 & $\begin{array}{c}27061 \\
.08\end{array}$ \\
\hline \multicolumn{4}{|c|}{ D. Employed in Large Town and Education } \\
\hline $\begin{array}{l}\text { Dependent } \\
\text { Variable: }\end{array}$ & $\begin{array}{c}\text { Years of } \\
\text { Education }\end{array}$ & Live in on & s by 2002 \\
\hline Estimator: & $\begin{array}{l}1^{\text {st }} \text { Stage } \\
\text { OLS }\end{array}$ & IV & Reduced form \\
\hline $\begin{array}{l}\text { ‘Affected’ by } \\
\text { Imaginary Reform }\end{array}$ & $.050(.010)$ & & $.014(.006)$ \\
\hline $\begin{array}{l}\text { Years of Education } \\
\text { Female }\end{array}$ & $.083(.006)$ & $\begin{array}{l}.285(.139) \\
-.042(.012)\end{array}$ & $-.019(.004)$ \\
\hline $\begin{array}{l}\text { Sample Size } \\
\text { R-squared }\end{array}$ & $\begin{array}{c}32509 \\
.06\end{array}$ & 32509 & $\begin{array}{c}32509 \\
.00\end{array}$ \\
\hline
\end{tabular}

Notes: Individuals with 9 or less years of education and known treatment status. All models control for year dummies and the municipality of growing up. Standard errors in parentheses are corrected for heteroscedasticity. 
Table 7 Summary statistics of the balanced panel

\begin{tabular}{|c|c|c|c|c|}
\hline & All & $\begin{array}{c}\text { Not Affected by } \\
\text { Reform }\end{array}$ & $\begin{array}{c}\text { Affected by } \\
\text { Reform }\end{array}$ & $\begin{array}{c}\text { Gap (Standard } \\
\text { error) }\end{array}$ \\
\hline \multicolumn{5}{|l|}{$\begin{array}{l}\text { Full Sample } \\
(\mathrm{N}=1081728)\end{array}$} \\
\hline Affected by Reform & .519 & .000 & 1.000 & \\
\hline Years of Education & 8.402 & 7.910 & 8.858 & $.948(.001)$ \\
\hline Age & 40.71 & 42.913 & 38.668 & $-4.245(.010)$ \\
\hline Employed & .720 & .727 & .713 & $-.014(.001)$ \\
\hline Migration & .010 & .009 & .012 & $.003(.000)$ \\
\hline \multicolumn{5}{|l|}{$\begin{array}{l}\text { Migration Sample } \\
\text { (N = 11230) }\end{array}$} \\
\hline Affected by Reform & .605 & .000 & 1.000 & \\
\hline Years of Education & 8.442 & 7.868 & 8.817 & $.949(.012)$ \\
\hline Age & 39.159 & 41.571 & 37.583 & $-3.988(.121)$ \\
\hline Employed & .548 & .539 & .554 & $.015(.008)$ \\
\hline
\end{tabular}

Table 8 The causal effect of education on annual rate of migration and employment

\begin{tabular}{|c|c|c|c|}
\hline \multicolumn{4}{|c|}{ A. Annual Migration and Education } \\
\hline Dependent Variable: & $\begin{array}{c}\text { Years of } \\
\text { Education }\end{array}$ & \multicolumn{2}{|c|}{ Probability of Moving in a Given Year (X100) } \\
\hline Estimator: & $\begin{array}{c}1^{\text {st }} \text { Stage } \\
\text { OLS }\end{array}$ & OLS & IV \\
\hline Affected by Reform & $.650(.002)$ & & \\
\hline Years of Education & & $-.142(.018)$ & .155 (.059) \\
\hline Female & $.052(.001)$ & $-.168(.020)$ & $-.184(.020)$ \\
\hline Sample Size & 1081728 & 1081728 & 1081728 \\
\hline R-squared & .41 & .00 & \\
\hline \multicolumn{4}{|c|}{ B. Employment and Education } \\
\hline Dependent Variable: & $\begin{array}{c}\text { Years of } \\
\text { Education }\end{array}$ & \multicolumn{2}{|c|}{ Probability of being employed (X100) } \\
\hline Estimator: & $\begin{array}{c}1^{\text {st }} \text { Stage } \\
\text { OLS }\end{array}$ & OLS & IV \\
\hline Affected by Reform & $.650(.002)$ & & \\
\hline Years of Education & & $5.053(.079)$ & $1.740(.229)$ \\
\hline Female & $.052(.001)$ & $-16.237(.086)$ & $-16.058(.087)$ \\
\hline Sample Size & 1081728 & 1081728 & 1081728 \\
\hline R-squared & .41 & .04 & \\
\hline
\end{tabular}

Notes: All models include cohort dummies, year dummies and fixed effects for municipality of growing up. X100 indicates that the coefficient and standard errors have been multiplied by 100 to improve readability. 
Table 9 The effect of additional education on timing of the first child

\begin{tabular}{lccc}
\hline & Years Education & Age when $1^{\text {st }}$ child born & Age when $1^{\text {st }}$ child born \\
\hline & $1^{\text {st }}$ stage OLS & OLS & IV \\
Affected by Reform & $.788(.066)$ & & \\
Years of Education & & $.084(.026)$ & $-.059(.054)$ \\
Female & $.051(.074)$ & $-2.802(.031)$ & $-2.794(.031)$ \\
& & & 53204 \\
Sample Size & 53204 & 53204 & 0.18 \\
R-squared & 0.47 & 0.18 & \\
\hline
\end{tabular}

Notes: All models include cohort dummies, year dummies and fixed effects for municipality of growing up. Standard errors in parentheses are corrected for heteroscedasticity.

Table 10 Education and likelihood to move to late-reforming municipality

\begin{tabular}{lccc}
\hline Dependent Variable: & $\begin{array}{c}\text { Years of } \\
\text { Education }\end{array}$ & \multicolumn{2}{l}{ Live in a late-reforming municipality by 2002} \\
\hline Estimator: & $\begin{array}{c}1^{\text {st }} \text { Stage } \\
\text { OLS }\end{array}$ & OLS & IV \\
\hline Affected by Reform & $.649(.009)$ & & \\
Years of Education & $.051(.004)$ & $-.028(.003)$ & $-.001(.009)$ \\
Female & 58497 & $.002(.003)$ & $-.001(.003)$ \\
Sample Size & .47 & 58497 & 58497 \\
R-squared & & .05 & \\
\hline
\end{tabular}

Notes: Individuals with 9 or less years of education and known treatment status. All models control for year dummies and the municipality of growing up. Standard errors in parentheses are corrected for heteroscedasticity. Municipality is defined 'late-reforming' if the first cohort to go through the new school system was 1953 or later. The number of observations is smaller than 67608 because some people move to municipalities, whose precise year of reform is not known. 


\section{Appendix}

Table A1 Data for Figures 1-3

\begin{tabular}{|c|c|c|c|c|c|}
\hline Variable: & $\begin{array}{c}\text { Years of } \\
\text { Education }\end{array}$ & $\begin{array}{c}\text { Years of } \\
\text { Education }\end{array}$ & Mobility rate & $\begin{array}{l}\text { Not attached to } \\
\text { hometown }\end{array}$ & $\begin{array}{l}\text { Moved in last } \\
\text { ten years }\end{array}$ \\
\hline Source: & Barro-Lee & Barro-Lee & Huber (2004) & Eurobarometer & Eurobarometer \\
\hline Year: & 1985 & 1990 & 1983 & 2001 & 2001 \\
\hline Austria (AUT) & 6.91 & 7.25 & 0.89 & 12 & 30.1 \\
\hline Belgium (BEL) & 8.61 & 8.88 & 0.92 & 17 & 34.8 \\
\hline Denmark (DNK) & $10, .41$ & 10.7 & 3.48 & 19 & 57.1 \\
\hline Spain (ESP) & 6.30 & 6.85 & 0.45 & 5 & 32.2 \\
\hline Finland (FIN) & 9.29 & 9.59 & 1.23 & 21 & 59.2 \\
\hline France (FRA) & 6.32 & 6.74 & & 19 & 41.5 \\
\hline Great Britain (GBR) & 8.52 & 8.76 & 1.58 & 18 & 52.1 \\
\hline Germany (GER) & 8.52 & 8.75 & 1.32 & 13 & 36.4 \\
\hline Greece (GRC) & 7.28 & 8.00 & & 9 & 28.9 \\
\hline Ireland (IRL) & 7.78 & 8.03 & & 10 & 28.3 \\
\hline Italy (ITA) & 6.16 & 6.48 & 0.77 & 13 & 19.9 \\
\hline Netherlands (NLD) & 8.49 & 8.74 & 1.67 & 33 & 53.4 \\
\hline Norway (NOR) & 7.98 & & $2.67 *$ & & \\
\hline Portugal (PRT) & 3.91 & 4.13 & 0.19 & 7 & 25.3 \\
\hline Sweden (SWE) & 9.44 & 9.48 & 1.5 & 17 & 55.7 \\
\hline United States (USA) & 11.47 & & $2.8^{* *}$ & & \\
\hline \multicolumn{2}{|c|}{$\begin{array}{l}\text { Correlation with education } \\
\text { (closest year) }\end{array}$} & & 0.78 & 0.54 & 0.75 \\
\hline \multicolumn{2}{|c|}{ * Own calculations 1986} & & ** US Census & 1983-84 & \\
\hline
\end{tabular}


Table A2 The causal effect of education on mobility, earnings and town size, by gender

\begin{tabular}{|c|c|c|}
\hline \multicolumn{3}{|c|}{ A. Mobility and Education } \\
\hline $\begin{array}{l}\text { Dependent } \\
\text { Variable: }\end{array}$ & \multicolumn{2}{|c|}{ Number inter-county migrations } \\
\hline Estimator: & IV - Men & IV - Women \\
\hline Years of Education & $.038(.019)$ & $.029(.019)$ \\
\hline Sample Size & 36115 & 31493 \\
\hline \multicolumn{3}{|c|}{ B. Employment and Education } \\
\hline $\begin{array}{l}\text { Dependent } \\
\text { Variable: }\end{array}$ & \multicolumn{2}{|c|}{ Years not employed (out of 17) } \\
\hline Estimator: & IV - Men & IV - Women \\
\hline Years of Education & $-.363(.042)$ & $-.243(.183)$ \\
\hline Sample Size & 36115 & 31493 \\
\hline \multicolumn{3}{|c|}{ C. Earnings and Education } \\
\hline $\begin{array}{l}\text { Dependent } \\
\text { Variable: }\end{array}$ & \multicolumn{2}{|c|}{ Log(Earnings), 1998} \\
\hline Estimator: & IV - Men & IV - Women \\
\hline Years of Education & $.078(.026)$ & $.074(.035)$ \\
\hline Sample Size & 31772 & 24790 \\
\hline \multicolumn{3}{|c|}{ D. Employed in Large Town and Education } \\
\hline $\begin{array}{l}\text { Dependent } \\
\text { Variable: }\end{array}$ & \multicolumn{2}{|c|}{ Live in one of 9 largest towns by 2002} \\
\hline Estimator: & IV - Men & IV - Women \\
\hline Years of Education & $.007(.010)$ & $.023(.011)$ \\
\hline Sample Size & 36115 & 31493 \\
\hline
\end{tabular}

Notes: Individuals with 9 or less years of education and known treatment status. All models control for year dummies and the municipality of growing up. Standard errors in parentheses are corrected for heteroscedasticity.

Table A3 Summary statistics for 1947-1958 birth cohorts with nine or less years of education (falsification sample)

Mean (Standard deviation)

Education Variables

Belong to three pre-reform cohorts (false treatment)

Years of education by 2002

Outcomes

Number of inter-county migrations

Years not employed (out of 17)

Earnings in 1998 (NOK)

Live in one of 9 largest towns by 2002

$.24(.43)$

Notes: Based on 32509 people with nine or less years of education in birth cohorts born between 1947 and 1958 
Table A4 Falsification exercise 2: The causal effect of education on mobility, for unaffected education groups

\begin{tabular}{|c|c|c|c|}
\hline \multicolumn{4}{|c|}{ A. Mobility and Education, if years of education is $10-12$} \\
\hline $\begin{array}{l}\text { Dependent } \\
\text { Variable: }\end{array}$ & $\begin{array}{c}\text { Years of } \\
\text { Education }\end{array}$ & \multicolumn{2}{|c|}{ Number inter-county migrations } \\
\hline Estimator: & $\begin{array}{l}1^{\text {st }} \text { Stage } \\
\text { OLS }\end{array}$ & IV & Reduced form \\
\hline $\begin{array}{l}\text { Affected by } \\
\text { Reform }\end{array}$ & $.054(.005)$ & & $.005(.004)$ \\
\hline $\begin{array}{l}\text { Years of Education } \\
\text { Female }\end{array}$ & $-.421(.003)$ & $\begin{array}{l}.084(.073) \\
.008(.031)\end{array}$ & $-.027(.002)$ \\
\hline $\begin{array}{l}\text { Sample Size } \\
\text { R-squared }\end{array}$ & $\begin{array}{c}370424 \\
.07\end{array}$ & 370424 & $\begin{array}{c}370424 \\
.01\end{array}$ \\
\hline \multicolumn{4}{|c|}{ B. Mobility and Education, if years of education is 13 or more } \\
\hline $\begin{array}{l}\text { Dependent } \\
\text { Variable: }\end{array}$ & $\begin{array}{c}\text { Years of } \\
\text { Education }\end{array}$ & Numb & rations \\
\hline Estimator: & $\begin{array}{l}1^{\text {st }} \text { Stage } \\
\text { OLS }\end{array}$ & IV & Reduced form \\
\hline $\begin{array}{l}\text { Affected by } \\
\text { Reform }\end{array}$ & $.016(.014)$ & & $.002(.007)$ \\
\hline $\begin{array}{l}\text { Years of Education } \\
\text { Female }\end{array}$ & $-.284(.006)$ & $\begin{array}{l}.146(.444) \\
-.067(.126)\end{array}$ & $-.109(.004)$ \\
\hline $\begin{array}{l}\text { Sample Size } \\
\text { R-squared }\end{array}$ & $\begin{array}{c}191227 \\
.01\end{array}$ & 191227 & $\begin{array}{c}191227 \\
.07\end{array}$ \\
\hline
\end{tabular}

Notes: All models control for year dummies and the municipality of growing up. Standard errors in parentheses are corrected for heteroscedasticity.

\section{Table A5 The causal effect of education on annual rate of migration and employment, by gender}

\begin{tabular}{lcc}
\hline A. Annual Migration and Education & & \\
\hline Dependent Variable: & \multicolumn{1}{l}{ Probability of Moving in a Given Year (X100) } \\
\hline Estimator: & IV - Men & IV - Women \\
\hline Years of Education & $.199(.074)$ & $.109(.077)$ \\
Sample Size & 577840 & 503888 \\
\hline B. Employment and Education & \multicolumn{1}{l}{ Probability of being employed (X100) } \\
\hline Dependent Variable: & IV - Men & IV - Women \\
\hline Estimator: & $2.111(.281)$ & $1.400(.377)$ \\
Years of Education & 577840 & 503888 \\
Sample Size & & \\
\hline
\end{tabular}

Notes: All models include cohort dummies, year dummies and fixed effects for municipality of growing up. X100 indicates that the coefficient and standard errors have been multiplied by 100 to improve readability. 
Table A6 Summary statistics including parental education, in full sample

Mean (standard deviation)

Years of education by 2002

$11.827(2.653)$

Affected by reform (Treated)

$.565(.496)$

Female

$.469(.499)$

Number of inter-county migrations

$.273(.705)$

Mother's education

No secondary education

$.694(.461)$

Lower secondary (non-academic)

$.156(.363)$

Lower secondary (academic)

$.100(.301)$

Upper secondary

$.049(.215)$

Father's education

No secondary education

$.763(.425)$

Lower secondary (non-academic)

$.093(.290)$

Lower secondary (academic)

$.075(.264)$

Upper secondary

$.069(.253)$

Notes: based on 481,209 observations in birth cohorts 1947-1958, for which the years of education and the number of regional migrations is available. Lower secondary education (non-academic) refers to framhaldsskole, ungdomsomsorg or fylkeskole, while the corresponding 'academic' refers to middelskole or realskole. Father's occupation has 257 categories.

Table A7 The causal effect of education on mobility, in full sample

\begin{tabular}{|c|c|c|c|}
\hline \multicolumn{4}{|c|}{ Mobility and Education } \\
\hline Dependent Variable: & $\begin{array}{c}\text { Years of } \\
\text { Education }\end{array}$ & \multicolumn{2}{|c|}{ Number inter-county migrations } \\
\hline Estimator: & $\begin{array}{c}1^{\text {st }} \text { Stage } \\
\text { OLS }\end{array}$ & OLS & IV \\
\hline Affected by Reform & $.105(.013)$ & & \\
\hline Years of Education & & $.033(.000)$ & $.068(.033)$ \\
\hline Female & $-.296(.008)$ & $-.036(.002)$ & $-.026(.010)$ \\
\hline Sample Size & 481209 & 481209 & 481209 \\
\hline R-squared & .01 & .03 & \\
\hline
\end{tabular}


Table A8 Summary statistics of the balanced panel (falsification sample)

\begin{tabular}{lcccc}
\hline & All & $\begin{array}{c}\text { Not Affected by } \\
\text { Reform }\end{array}$ & $\begin{array}{c}\text { Affected by } \\
\text { Reform }\end{array}$ & $\begin{array}{c}\text { Gap (Standard } \\
\text { error) }\end{array}$ \\
\hline $\begin{array}{l}\text { Full Sample } \\
\mathbf{N}=\mathbf{5 2 0 1 4 4 )}\end{array}$ & & & \\
Affected by reform & .478 & & & \\
Years of education & 7.910 & 0 & 1 & $.225(.001)$ \\
Age & 42.913 & 7.803 & 8.028 & $-2.554(.014)$ \\
Employed & .728 & 44.133 & 41.579 & $-.012(.001)$ \\
Migration & .009 & .733 & .721 & $.002(.000)$ \\
Migration Sample & & .008 & .010 & \\
(N= 4438) & & & & \\
Affected by reform & .534 & & & $-.243(.012)$ \\
Years of education & 7.868 & 0 & 7.981 & $-2.813(.121)$ \\
Age & 41.571 & 7.738 & 40.259 & $-.031(.013)$ \\
Employed & .539 & 43.072 & .524 & \\
\hline
\end{tabular}

Table A9 Falsification exercise: The causal effect of education on annual rate of migration and employment

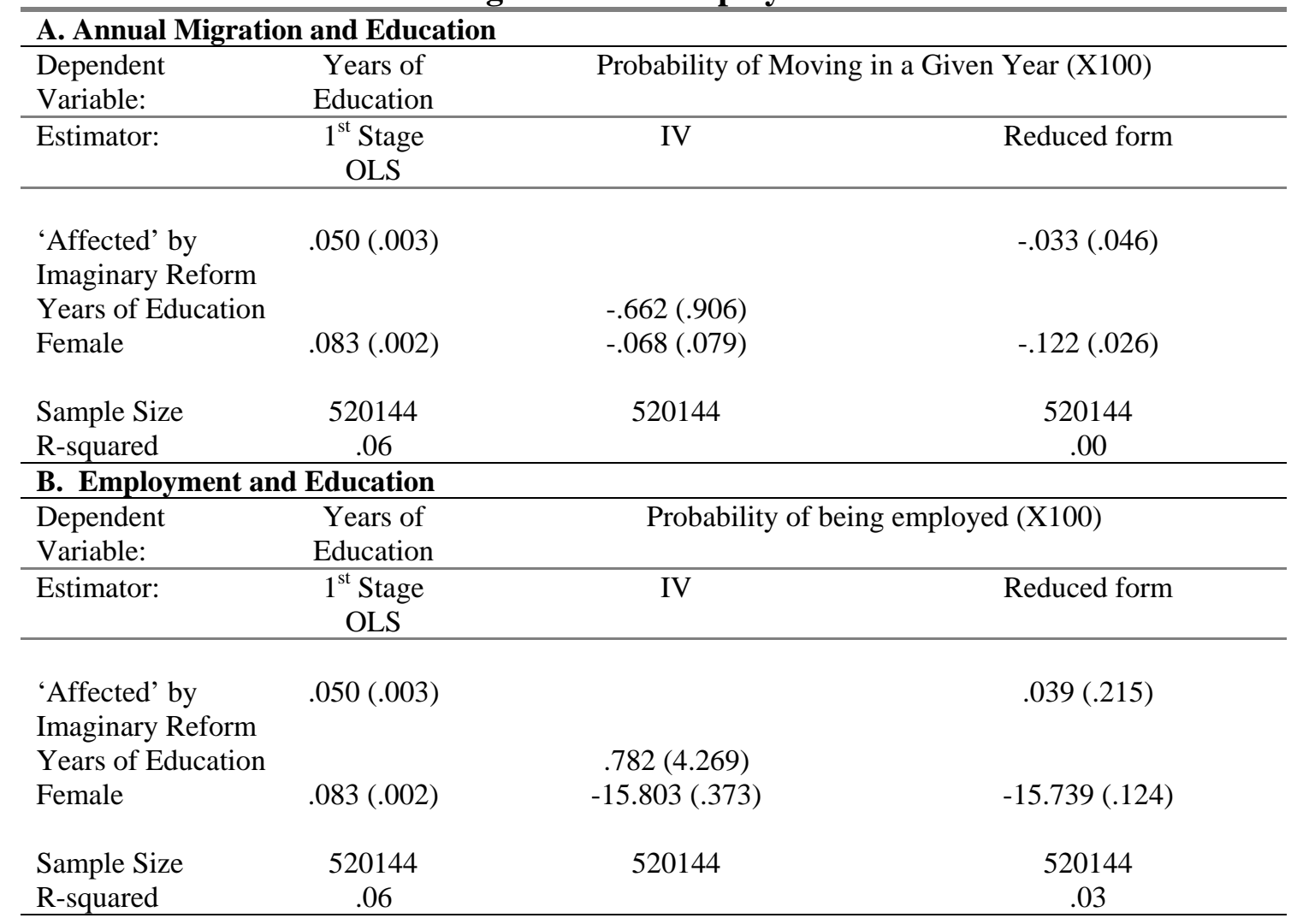


Table A10 Age specific IV estimations of the migration rate

\begin{tabular}{lccc}
\hline A. Age group 18-36 & \multicolumn{3}{l}{} \\
\hline $\begin{array}{l}\text { Dependent } \\
\text { variable: }\end{array}$ & $\begin{array}{c}\text { Probability of } \\
\text { moving (X100) }\end{array}$ & $\begin{array}{c}\text { Probability of } \\
\text { moving (X100) }\end{array}$ & $\begin{array}{c}\text { Probability of } \\
\text { moving (X100) }\end{array}$ \\
\hline Age group & $28-36$ & $37-45$ & 46-54 \\
\hline Estimator: & IV & IV & IV \\
$\begin{array}{l}\text { Years of Education } \\
\text { Female }\end{array}$ & $.301(.148)$ & $.058(.070)$ & $.286(.106)$ \\
Sample Size & $-.227(.047)$ & $-.202(.026)$ & $-.076(.037)$ \\
\hline
\end{tabular}

Notes: All models are linear probability IV models, and cohort dummies, year dummies and fixed effects of municipality of growing up. X100 indicates that the coefficient and standard errors have been multiplied by 100 to improve readability. 